Kinetics and impacting factors of $\mathrm{HO}_{2}$ uptake onto submicron atmospheric aerosols during a

3 Jun Zhou $^{\mathrm{abb}, c_{*}}$, Kei Sato ${ }^{\mathrm{d}}$, Yu Bai $^{\mathrm{e}}$, Yukiko Fukusaki ${ }^{\mathrm{f}}$, Yuka Kousa ${ }^{\mathrm{f}}$, Sathiyamurthi Ramasamy ${ }^{\mathrm{d}}$,

4 Akinori Takami $^{\mathrm{d}}$, Ayako Yoshino ${ }^{\mathrm{d}}$, Tomoki Nakayama ${ }^{\mathrm{g}}$, Yasuhiro Sadanaga ${ }^{\mathrm{h}}$, Yoshihiro

5 Nakashima $^{\mathrm{i}}, \mathrm{Jiaru} \mathrm{Li}^{\mathrm{c}}$, Kentaro Murano ${ }^{\mathrm{c}}$, Nanase Kohno ${ }^{\mathrm{c}}$, Yosuke Sakamoto ${ }^{\mathrm{c}, \mathrm{de}}$, Yoshizumi

$6 \quad \mathrm{Kajii}{ }^{\mathrm{c}, \mathrm{d}, \mathrm{e} *}$

$7 \quad{ }^{a}$ Institute for Environmental and Climate Research, Jinan University, 511443 Guangzhou, China

$8{ }^{\mathrm{b}}$ Guangdong-Hongkong-Macau Joint Laboratory of Collaborative Innovation for Environmental Quality,

9 Guangzhou 511443, China

$10{ }^{\mathrm{c}}$ Graduate School of Global Environmental Studies, Kyoto University, Kyoto, 606-8501, Japan

$11{ }^{\mathrm{d}}$ Center for Regional Environmental Research, National Institute for Environmental Studies, Tsukuba,

12 Ibaraki 305-8506, Japan

13 e'Graduate School of Human and Environmental Studies, Kyoto University, Kyoto 606-8501, Japan

14 fYokohama Environmental Science Research Institute, Yokohama Kanagawa 221-0024, Japan

15 gaculty of Environmental Science and Graduate School of Fisheries and Environmental Sciences, Nagasaki

16 University, Nagasaki 852-8521, Japan

17 hGraduate School of Engineering, Osaka Prefecture University, Sakai, Osaka 599-8531, Japan

18 iGraduate School of Agriculture, Tokyo University of Agriculture and Technology, 3-5-8 Saiwai-cho, Fuchu,

19 Tokyo 183-8538, Japan

20

\section{*Corresponding author.}

Graduate School of Global Environmental Studies, Kyoto University, Kyoto 606-8501, Japan E-mail address: kajii.yoshizumi.7e@kyoto-u.ac.jp and junzhou@jnu.edu.cn 


\section{Abstract}

$\mathrm{HO}_{2}$ uptake kinetics onto ambient aerosols play pivotal roles in tropospheric chemistry but are not fully understood. Field measurements of aerosol chemical and physical properties should be linked to molecular level kinetics; however, given that the $\mathrm{HO}_{2}$ reactivity of ambient aerosols is low, traditional analytical techniques are unable to achieve this goal. We developed an online approach to precisely investigate (i) the $\mathrm{HO}_{2}$ reactivity of ambient gases and aerosols and (ii) $\mathrm{HO}_{2}$ uptake coefficients onto ambient aerosols $(\gamma)$ during 2019 air quality study (AQUAS) in Yokohama, Japan. We identified the effects of individual chemical components of ambient aerosols on $\gamma$. The results verified in laboratory studies on individual chemical components: transition metals play a key role in $\mathrm{HO}_{2}$ uptake processes and chemical components indirectly influence such processes (i.e., through altering aerosol surface properties or providing active sites), with smaller particles tending to yield higher $\gamma$ values than larger particles owing to the limitation of gas phase diffusion is smaller with micrometer particles and the distribution of depleting species such as transition metal ions is mostly distributed in accumulation mode of aerosol. The modeling of $\gamma$ utilized transition metal chemistry derived by previous studies, further confirming our conclusion. However, owing to the high NO concentrations in Yokohama, peroxy radical loss onto submicron aerosols has a negligible impact on $\mathrm{O}_{3}$ production rate and sensitivity regime.

\section{Introduction}

As an important atmospheric trace gas, the hydroperoxyl radical $\left(\mathrm{HO}_{2}\right)$ links many of the key oxidants in the troposphere, including the hydroxyl radical $(\mathrm{OH})$, nitrate radical $\left(\mathrm{NO}_{3}{ }^{-}\right)$, ozone $\left(\mathrm{O}_{3}\right)$, and hydrogen peroxide $\left(\mathrm{H}_{2} \mathrm{O}_{2}\right)$ (Logan et al., 1981; Chen et al., 2001; Jaeglé et al., 2000; Sommariva et al., 2004; Jacob, 2000). However, its observed concentration in field measurements has not yet been fully explained by sophisticated models (known as the "HOx dilemma") (Stone et al., 2012; Creasey et al., 1997; Kanaya et al., 2007b; Whalley et al., 2010; Millán et al., 2015), although it can be mostly solved

in the conditions of clean marine air or stratospheric air where NO concentration is low or aerosol 

2004; Kanaya et al., 2007a). Owing to the short atmospheric lifetime of $\mathrm{HO}\left(=\mathrm{OH}+\mathrm{HO}_{2}+\mathrm{RO}_{2}\right)$, the HOx reactivity measurement can provide a robust test of its complex chemistry (Heard and Pilling, 2003). The $\mathrm{HO}_{2}$ uptake kinetics of ambient aerosols, including $\mathrm{HO}_{2}$ reactivity $\left(k_{\mathrm{a}}\right)$ and the $\mathrm{HO}_{2}$ uptake coefficient $(\gamma)$, influence many atmospheric processes, including ozone formation rates and their sensitivity to $\mathrm{NO}_{\mathrm{X}}$ (Sakamoto et al., 2019), $\mathrm{H}_{2} \mathrm{O}_{2}$ formation thus aerosol properties (Thornton et al., 2008). With $\gamma>0.1, \mathrm{HO}_{2}$ concentration can also be influenced under conditions such as low [NO] or high aerosol loading (Lakey et al., 2015; Mao et al., 2013b; Martínez et al., 2003; Tie et al., 2001, Jacob, 2000; Matthews et al., 2014). These effects make the $\mathrm{HO}_{2}$ uptake kinetics of ambient aerosols indirectly influence human health and climate change. Bedjanian et al., 2005; Thornton et al., 2008; George et al., 2013; Lakey et al., 2016a; Lakey et al., 2016b; Matthews et al., 2014; Cooper and Abbatt, 1996; Hanson et al., 1992; Thornton and Abbatt, 2005; González Palacios et al., 2016; Mozurkewich et al., 1987; Remorov et al., 2002; Jaeglé et al., 2000; Loukhovitskaya et al., 2009; Stone et al., 2012), $\mathrm{HO}_{2}$ uptake coefficients onto different types of aerosol can span several orders of magnitude $(\sim 0.002-1)$, which can be affected by many parameters, such as droplet/particle size and composition, the presence of dissolved reactive gases (Mozurkewich et al., 1987), and environmental conditions (i.e., relative humidity $(\mathrm{RH}), \mathrm{pH}$, and $T$ ). In the absence of metals, the uptake of $\mathrm{HO}_{2}$ by ambient aerosols is believed to occur via the acid-base dissociation of $\mathrm{HO}_{2}(p K a=4.7)$, followed by electron transfer from $\mathrm{O}_{2}^{-}$to $\mathrm{HO}_{2}(\mathrm{aq})$, producing $\mathrm{H}_{2} \mathrm{O}_{2}(\mathrm{Jacob}, 2000$;

73 Thornton et al., 2008; Zhou et al., 2019b). However, laboratory studies have shown that certain transition metals (i.e., $\mathrm{Cu}(\mathrm{II})$ and $\mathrm{Fe}(\mathrm{II})$ ) can act as catalysts and accelerate $\mathrm{HO}_{2}$ uptake rates onto many chemical compounds (Thornton et al., 2008; Taketani et al., 2008; Taketani et al., 2012, Cooper and Abbatt, 1996). Owing to the sufficiently high metal concentrations in tropospheric aerosols, as shown in previous field measurements (Hofmann et al., 1991; Wilkinson et al., 1997; Guieu et al., 1997; Manoj et al., 2000; Halstead et al., 2000; Siefert et al., 1998; Sedlak and Hoigné, 1993; Guo et al., 2014), recent studies have proposed that $\gamma$ may be dominated by metals contained in the aerosol. This can lead to the 

and sulfate (Mozurkewich et al., 1987; Cooper and Abbatt, 1996; Gonzalez et al., 2010; Loukhovitskaya et al., 2009; Mao et al., 2010; Macintyre and Evans, 2011), which are important in the evolution of the chemical composition and physical properties of particles (George and Abbatt, 2010; George et al., 2008). The available data concerning $\mathrm{HO}_{2}$ uptake kinetics onto ambient aerosols are insufficient for quantitative consideration owing to the much lower $k_{\mathrm{a}}$ value, as compared with the $\mathrm{HO}_{2}$ reactivity of ambient gases $\left(k_{\mathrm{g}}\right)$. Therefore, they are below the detection limits of the current instruments.

To our knowledge, aside from us, only one study has measured $\gamma$, using an offline method that integrated ambient aerosols over size and time (Taketani et al., 2012). Considering that the offline method may distort $\gamma$, we developed an online approach to evaluate $\mathrm{HO}_{2}$ uptake kinetics onto ambient aerosols. This method was successfully applied in Kyoto, Japan, in summer 2018, using a versatile aerosol concentration enrichment system (VACES) and a technique combining laser-flash photolysis with laser-induced fluorescence (LFP-LIF) (Zhou et al., 2019b). The obtained average $\gamma$ value $(\sim 0.24)$ was comparable with the previous values used for modeling studies ( 0.2) (Stadtler et al., 2018; Jacob, $2000)$. However, the large standard deviation $( \pm 0.20,1 \sigma)$ of $\gamma$ along with the measurement time suggest that many other parameters might play a role, e.g., the measurement setup, aerosol characteristics, $T$, and RH. and different properties of the air masses from mainland Japan and the coast, as the measurement site. This is part of the Air QUAlity Study (AQUAS) campaigns. The chemical and physical properties of ambient aerosols were quantified in real-time. To test their influence on $k_{\mathrm{a}}$ and $\gamma$, we conducted correlation matrix analysis coupled with the bootstrap method and classified the arriving air masses from different directions. Further, the main mechanism of $\gamma$ was investigated by comparing the realtime quantified $\gamma$ values with the modeled values. The impact of the peroxy radical's loss onto ambient aerosols on air quality is evaluated through their impact on ozone formation rates and their sensitivity to $\mathrm{NO}_{\mathrm{X}}$. The results obtained here will for better estimation of the heterogeneous reaction between $\mathrm{HO}_{2}$ and ambient aerosols in sophisticated air quality models. 


\section{Materials and methods}

\subsection{Sampling sites}

The measurement campaign was conducted at Yokohama Environmental Science Research Institute in Yokohama, Japan (location: $35^{\circ} 28^{\prime} 52.8^{\prime \prime} \mathrm{N}, 139^{\circ} 39^{\prime} 30.3 " \mathrm{~B}$ ), from July 24 to August 03, 2019. The sampling ports of the instruments were placed approximately $25 \mathrm{~m}$ above the ground. Figure S1 shows the air mass directions during the campaign, which can be classified into two categories: (i) from the sea to the north, toward Yokohama City ( $\sim 19 \%$ of the experimental period: from 12:00 July 25 to 12:00 July 27, 2019) and (ii) from the mainland toward Yokohama City ( $81 \%$ of the experimental period). This classification was intended to distinguish the chemical properties of aerosols arriving from the mainland and the ocean, and to consequently quantify their impacts on $k_{\mathrm{a}}$ and $\gamma$.

\subsection{Measurement strategies, instrumentation, and related data analysis}

LFP-LIF and VACES In situ ambient air $\mathrm{HO}_{2}$ reactivity was measured using LFP-LIF, which was adapted from a laser-induced pump and probe $\mathrm{OH}$ reactivity measurement technique. This approach has been successfully employed for gas and aerosol phase $\mathrm{HOx}\left(=\mathrm{OH}+\mathrm{HO}_{2}\right)$ reactivity measurements (Sadanaga et al., 2004; Miyazaki et al., 2013; Sakamoto et al., 2018). Further details concerning the $\mathrm{HO}_{2}$ reactivity measurements are described in the Supporting Information (SI). To compensate for the relatively low ambient aerosol concentrations and thus the low $k_{\mathrm{a}}$, a setup with VACES and an autoswitching aerosol filter was used before LFP-LIF. The enrichment factor of the ambient aerosol surface area $(E)$ was calculated from the difference between the surface areas measured before and after VACES by two scanning mobility particle sizers (SMPSs) (see SI).

$\mathrm{HO}_{2}$ reactivities in ambient air caused by two modes were measured: (a) the gas phase mode with aerosol filter on, the $\mathrm{HO}_{2}$ reactivities are represented as $k_{\mathrm{g}}$, and (b) the gas + enriched aerosol phase mode with aerosol filter off, the $\mathrm{HO}_{2}$ reactivities are represented as $k_{\mathrm{g}}+E k_{\mathrm{a}}$, where $E$ represents the enrichment factor of $k_{\mathrm{a}}, E k_{\mathrm{a}}$ represents the total $\mathrm{HO}_{2}$ reactivities caused by enriched ambient aerosols, the usage of $E k_{\mathrm{a}}$ is based on the assumption that $\mathrm{HO}_{2}$ uptake with aerosol particles follows the pseudofirst-order rate law. We modeled $k_{\mathrm{g}}$ in both modes using a theory identified previously (see $\mathrm{SI}: \mathrm{HO}_{2}$ 

differences between measured and modeled $k_{\mathrm{g}}$ in mode (a) enabled us to establish their interrelationship and to check instrument stability. The differences between $\left(k_{\mathrm{g}}+E k_{\mathrm{a}}\right)$ and the modeled $k_{\mathrm{g}}$ in mode (b) are considered as the enriched aerosol phase $\mathrm{HO}_{2}$ reactivity $\left(E k_{\mathrm{a}}\right)$. The total $\mathrm{HO}_{2}$ reactivity decay profile follows single-exponential decay:

where $k_{\mathrm{bg}}$ denotes the zero air background obtained by injecting zero air with the same $\mathrm{RH}$ as the realtime ambient value into the reaction cell every $24 \mathrm{~h}$ for $30 \mathrm{~min}$. The RH was controlled by passing some of the zero air through a water bubbler. The value of $k_{\mathrm{bg}}$ was subtracted separately on each day. The variability of $k_{\mathrm{bg}}$ (i.e., the reproducibility of the laser system) was calculated as the standard deviation of the response of repeated measurements on different days. It was found to be $\sim 4 \%$, which is slightly higher than the instrument precision (3\%). A 30-min average calculation was applied to the data to reduce data fluctuation. The observed $\mathrm{HO}_{2}$ uptake coefficients onto ambient aerosols $\left(\gamma_{\mathrm{obs}}\right)$ can be calculated from the dependence of $E k_{\mathrm{a}}$ on $\gamma_{\mathrm{obs}}$ :

$$
E k_{\mathrm{a}}=\frac{\gamma_{\mathrm{obs}} \omega_{\mathrm{HO}_{2}} E \mathrm{~S}}{4}
$$

where $E \mathrm{~S}$ and $\omega_{\mathrm{HO}_{2}}$ represent the enriched surface area of ambient aerosol after VACES $(\sim 12.5)$ and the mean thermal velocity of $\mathrm{HO}_{2}\left(\sim 437.4 \mathrm{~m} \mathrm{~s}^{-1}\right)$, respectively. Therefore, the $\mathrm{HO}_{2}$ reactivity of ambient aerosol $\left(k_{\mathrm{a}}\right)$ can be obtained from $E k_{a}$ by dividing by the enrichment factor $E$.

High resolution-time of flight-aerosol mass spectrometry (HR-ToF-AMS) A field-deployable HRToF-AMS (Aerodyne Research Inc.) (DeCarlo et al., 2006) was used for the characterization of the non-refractory aerosol mass with a time resolution of $\sim 3 \mathrm{~min}$. The HR-ToF-AMS measured the total organic aerosol (OA), sulfate $\left(\mathrm{SO}_{4}{ }^{2-}\right)$, nitrate $\left(\mathrm{NO}_{3}{ }^{-}\right)$, ammonium $\left(\mathrm{NH}_{4}{ }^{+}\right)$, chloride $\left(\mathrm{Cl}^{-}\right)$, and the two most dominant oxygen-containing ions in the OA spectra, i.e., mass-to-charge ratios of $\mathrm{m} / \mathrm{z}=44$ (Org44, mostly $\mathrm{CO}_{2}{ }^{+}$) and $\mathrm{m} / \mathrm{z}=43\left(\mathrm{Org} 43\right.$, mainly $\mathrm{C}_{2} \mathrm{H}_{3} \mathrm{O}^{+}$for the oxygenated $\mathrm{OA}$ and $\mathrm{C}_{3} \mathrm{H}_{7}^{+}$for the hydrocarbon-like OA) (Ng et al., 2011). The fractions of Org44 and Org43 in OA are represented as $f_{44}$ and $f_{43}$, respectively. Ambient air was sampled through a critical orifice into an aerodynamic lens, which 

by impaction on a resistively heated surface $\left(\sim 600^{\circ} \mathrm{C}\right)$ and ionized by electron ionization $(70 \mathrm{eV})$. The $\mathrm{m} / \mathrm{z}$ values of the resulting fragments were determined using a ToF mass spectrometer. Data were analyzed using the ToF-AMS software SQUIRREL and PIKA. Data were not corrected for lens transmission efficiency. Standard relative ionization efficiencies (RIE) were used for organics (RIE $=$ $1.4)$, nitrate $(\mathrm{RIE}=1.1)$, chloride $(\mathrm{RIE}=1.3)$, sulfate $(\mathrm{RIE}=1.12)$, and ammonium $(\mathrm{RIE}=4)$. Concentration data were obtained from background-subtracted stick-mass data (low-mass-resolutionbase mass concentration data, which are calibrated using ammonium sulfate particles) and determined assuming a collection efficiency (CE) of 0.5 .

Filter-based photometer Real-time measurement of the equivalent black carbon (eBC) was performed using a 5-wavelength dual-spot absorption photometer (MA300, AethLabs, San Francisco, CA, USA), which performed an online correction for possible artefacts resulting from filter loading and multiple scattering (Drinovec et al., 2015). In this study, eBC data obtained from light attenuation at a wavelength of $880 \mathrm{~nm}$ were used to avoid possible contributions from brown carbon; the time resolution was $\sim 1$ $\min$.

Trace elements Fourteen trace elements ( $\mathrm{Al}, \mathrm{V}, \mathrm{Cr}, \mathrm{Mn}, \mathrm{Co}, \mathrm{Ni}, \mathrm{Cu}, \mathrm{Zn}, \mathrm{As}, \mathrm{Se}, \mathrm{Sr}, \mathrm{Cd}, \mathrm{Ba}$, and $\mathrm{Pb}$ ) were measured using an offline method at two-day intervals from 21 July to 5 August 2019. The suspended particle matter (SPM) was collected onto $623.7 \mathrm{~cm}^{2}$ size quartz fiber filters (Pallflex Tissuquartz 2500QAT-UP), which had an available collecting area of $405.84 \mathrm{~cm}^{2}$, using a high-volume sampler (1000 L min $\mathrm{m}^{-1}$. Approximately $2 \mathrm{~cm}^{2}$ of each filter was cut into pieces and placed into a polytetrafluoroethylene (PTFE) pressure digestion tank with $1 \mathrm{~mL} 49 \%$ hydrofluoric acid (HF) and 5 $\mathrm{mL} 69 \%$ nitric acid $\left(\mathrm{HNO}_{3}\right)$. A Thermo Fisher X2 Series inductively coupled plasma mass spectrometer (ICP-MS) was then used to determine metal concentrations. By assuming that the metal fractions were the same in SPM and $\mathrm{PM}_{1}$ (aerosol particles with aero-dynamic diameters less than $1 \mu \mathrm{m}$ ), the concentrations in $\mathrm{PM}_{1}$ were estimated according to the tested metal concentrations in SPM and the ratio between SPM and $\mathrm{PM}_{1}$ measured in-situ. 
Water-soluble inorganic species $\mathrm{NR}-\mathrm{PM}_{1}$ water-soluble inorganic species (including $\mathrm{Na}^{+}, \mathrm{SO}_{4}{ }^{2-}, \mathrm{NH}_{4}{ }^{+}$, $\mathrm{NO}_{3}{ }^{-}, \mathrm{Cl}^{-}, \mathrm{Ca}^{2+}, \mathrm{K}^{+}, \mathrm{Mg}^{2+}$ ) used for the ISORROPIA-II model were also measured using offline method, as described above. For extraction, we cut $1 / 4$ of a $47 \mathrm{~mm}$ filter punched from the original collected filter and placed it in $10 \mathrm{~mL}$ of ultrapure water $\left(18.2 \mathrm{MW} \mathrm{cm}^{-1}\right)$ in a centrifuge tube. This was followed by $15 \mathrm{~min}$ of ultrasonication in a $30^{\circ} \mathrm{C}$ water bath. The solution was then vortexed (Vortex Genie 2 , Scientific Industries, USA) for 1 min to ensure homogeneity and filtered through syringe filter with pore size of $0.45-\mu \mathrm{m}$ (Advantec Dismic-25, PTFE). An Ion Chromatograph (IC, ICS1600, DIONEX, USA) was employed to determine the concentrations of these inorganic ions in the extracted solution. Scanning Mobility Particle Sizers (SMPS) Particle mass and surface area before and after VACES were determined using two SMPSs (model 3936L72 and 3936L75, TSI, Shoreview, MN, USA) that measured particle size distribution at $14.1-736.5 \mathrm{~nm}$ and $14.6-661.2 \mathrm{~nm}$ at 5-min intervals.

Gas phase monitors $\mathrm{NO}_{2}$ was measured by cavity attenuated phase shift (CAPS, Aerodyne Research, USA, at 1-s intervals), NOy - NO by chemiluminescence (Model 42i-TL, Thermo, at 10-s intervals), CO by Thermo CO analyzer of nondispersive infrared spectroscopy (Model 48i-TLE, Thermo Scientific, USA, at 10-s time intervals), and $\mathrm{O}_{3}$ by UV absorption (Model 1150, Dylec, AMI Co., Ltd, at 10-s time intervals). HCHO was determined by high performance liquid chromatography (HPLC; 1260 Infinity, Agilent Technologies Inc, USA) from 14:00 July 29, to 12:00 August 3, 2019. An average value of $\sim 2$ ppb was used for the data analysis.

ISORROPIA-II model $\mathrm{NR}-\mathrm{PM}_{1}$ water-soluble inorganic species (including $\mathrm{Na}^{+}, \mathrm{SO}_{4}{ }^{2-}, \mathrm{NH}_{4}{ }^{+}, \mathrm{NO}_{3}{ }^{-}, \mathrm{Cl}$

$\left.{ }^{-}, \mathrm{Ca}^{2+}, \mathrm{K}^{+}, \mathrm{Mg}^{2+}\right)$ and meteorological parameters including temperature and $\mathrm{RH}$ were used to calculate the aerosol $\mathrm{pH}$ and liquid water content based on the ISORROPIA-II model (Fountoukis and Nenes, 2007). We ran ISORROPIA-II in "reverse" mode and the particles were assumed to be deliquescent, i.e., in metastable mode (Hennigan et al., 2015). The thermodynamic equilibrium of the $\mathrm{NH}_{4}{ }^{+}-\mathrm{SO}_{4}{ }^{2-}-\mathrm{NO}_{3}$ system case was used for modeling.

\section{Results and discussion}


211 The measured total $\mathrm{HO}_{2}$ reactivities were compared against the modeled gas phase $\mathrm{HO}_{2}$ reactivity under

212 the experimental conditions both with and without the aerosol phase. Without the aerosol phase, the

213 modeled $k_{\mathrm{g}}$ values are calculated according to the description in Sect. 2.2, which are not statistically

214 different with the measured $k_{\mathrm{g}}$ values (Fig. 1a second panel, T-test, $p=0.49$, with alpha $=0.05$ ),

215 indicating that $\mathrm{HO}_{2}$ loss in the reaction cell was dominated by its reaction with $\mathrm{NO}_{2}$ in the LFP-LIF

216 system. With the aerosol phase, the measured $\left(E k_{\mathrm{a}}+E_{\mathrm{g}}\right)$ and modeled values $\left(\approx E_{\mathrm{g}}\right)$ were significantly

217 different (see Fig. 2b, first panel, T-test, $p=0.04$, with alpha $=0.05$ ). The differences were considered

218 to be the $\mathrm{HO}_{2}$ reactivities of enriched ambient aerosols $\left(E k_{\mathrm{a}}\right) . E k_{\mathrm{a}}$ ranged between $0.01 \mathrm{~s}^{-1}\left(25^{\text {th }}\right.$ percentile $)$

219 and $0.1 \mathrm{~s}^{-1}\left(75^{\text {th }}\right.$ percentile), with an average value of $0.066 \pm 0.062 \mathrm{~s}^{-1}$, the corresponding $k_{\mathrm{a}}$, calculated by dividing $E k_{\mathrm{a}}$ by $E$, ranged between $0.001 \mathrm{~s}^{-1}\left(25^{\text {th }}\right.$ percentile) and $0.08 \mathrm{~s}^{-1}\left(75^{\text {th }}\right.$ percentile), with an

221 average value of $0.005 \pm 0.005 \mathrm{~s}^{-1}$. The error for $E k_{\mathrm{a}}$ was estimated as $\sim 0.05 \mathrm{~s}^{-1}$, calculated as the

222 propagated errors from $k_{\mathrm{g}}+E k_{\mathrm{a}}$ (equals to the systematic error of the instrument, $\sim 0.05 \mathrm{~s}^{-1}$ ) and the modelled $k_{\mathrm{g}}$ in mode $(\mathrm{b})\left(\sim 0.001 \mathrm{~s}^{-1}\right)$. Accordingly, the errors for $k_{\mathrm{a}}$ was estimated as $\sim 0.004 \mathrm{~s}^{-1}$ (from

224 the obtained error of $E k_{a}$ by dividing by the enrichment factor $E$ ). The corresponding $\gamma$, calculated from Eq. 2, ranged from 0.05 ( $25^{\text {th }}$ percentile $)$ to 0.33 ( $75^{\text {th }}$ percentile $)$, with an average value of $0.23 \pm$ details are given in the SI). 

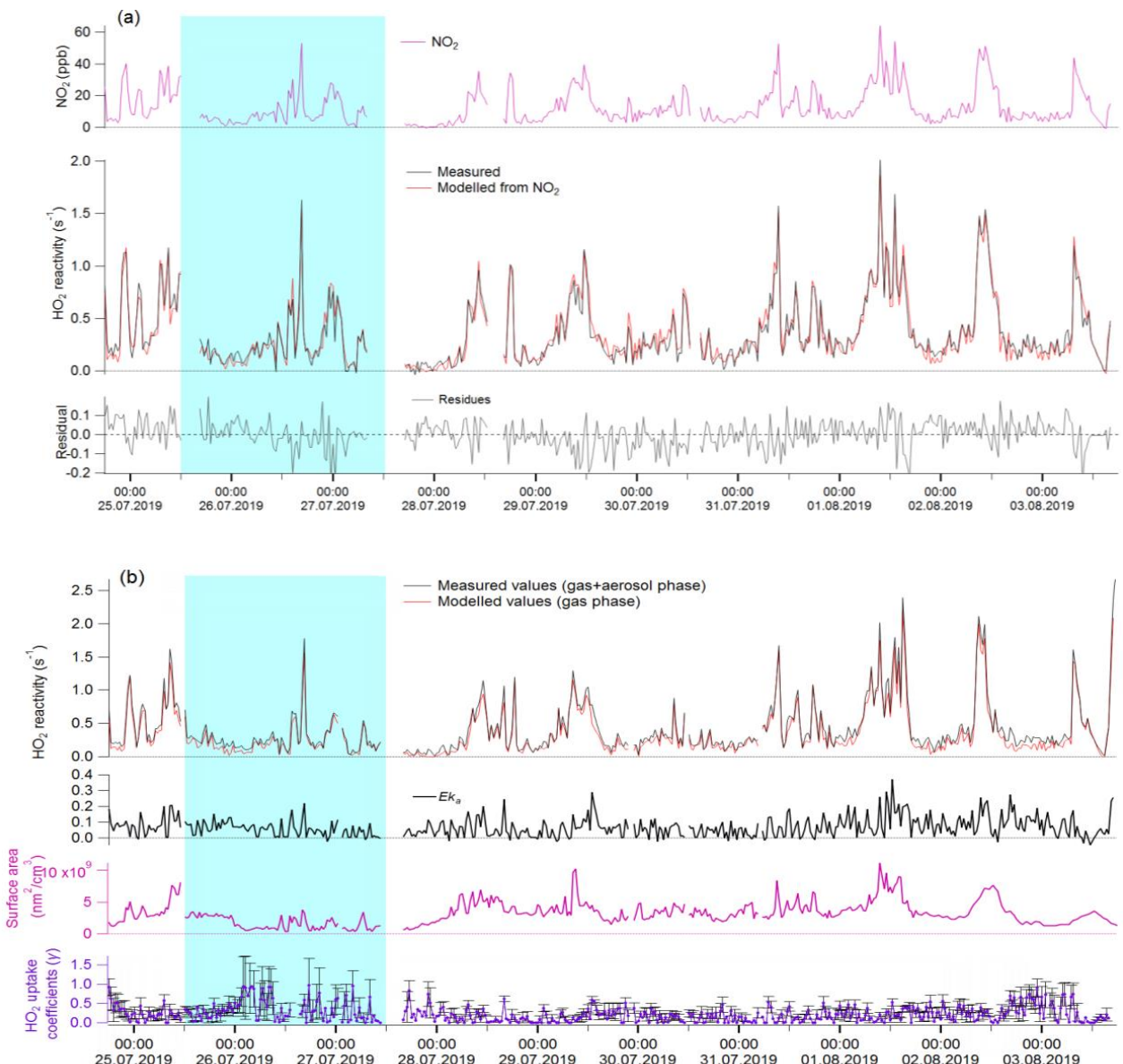

Figure 1: Temporal variation of parameters under different experimental conditions. (a) Without aerosol phase: $1^{\text {st }}$ panel: measured $\mathrm{NO}_{2}$ concentrations ( $\left.\mathrm{ppb}\right) ; 2^{\text {nd }}$ panel: measured (red line) and modeled (black line) $k_{\mathrm{g}} ; 3^{\text {rd }}$ panel: fitting residues of modeled $k_{\mathrm{g}}$ values, ranging from -0.04 ( 25 percentile) to 0.05 ( 75 percentile), which are considered to be the systematic error of the LFP-LIF instrument. (b) Gas + aerosol phase: 1st panel: measured total $\mathrm{HO}_{2}$ reactivity $\left(k_{\mathrm{g}}+E k_{\mathrm{a}}\right)$ and modeled $k_{\mathrm{g}} ; 2^{\text {nd }}$ panel: $E k_{\mathrm{a}}$, calculated from the difference between the measured and modeled values from the $1^{\text {st }}$ panel; $3^{\text {rd }}$ panel: the surface area of the enriched ambient aerosols $(E S)$; $4^{\text {th }}$ panel: $\gamma$ calculated from $E k_{\mathrm{a}}$ and $E \mathrm{~S}$ according to Eq. 2. The blue shaded area represents the air masses from group i (from coast), the remainder is from group ii (from mainland). The errors for $\gamma$ were estimated as the propagated errors of $k_{\mathrm{a}}\left(\sim 0.004 \mathrm{~s}^{-1}\right)$ and the surface area $(\sim 8 \%)$, based on the systematic errors of the instrument.

Statistical significance analysis showed that the average $\gamma$ value of group i $(0.35 \pm 0.28)$ is significantly

higher than that of group ii $(0.21 \pm 0.16)$ (calculated $p=4.9 \mathrm{E}-5$; Mann-Whitney), indicating that the air

masses from the ocean yield higher $\gamma$ values than the air masses from mainland Japan. This difference

maybe influenced by many factors, for example, the mass accommodation coefficients $\left(\alpha^{\mathrm{HO}_{2}}\right)$, which are driven by the physical and chemical properties of the aerosols. Studies have shown that $\alpha^{\mathrm{HO}_{2}}$ are 
typically $~ 0.2$ and 0.5 for organics and inorganics, respectively (Lakey et al., 2016b, 2016a; Taketani et al., 2008, 2009; Thornton et al., 2005; Moon et al., 2018; George et al., 2013; Mozurkewich et al., 1987), while for aerosols with transition metals, $\gamma$ values could be limited only by $\alpha \mathrm{HO}_{2}$ (Mozurkewich et al., 1987). Thus we will discuss such differences in the aerosols arriving from the ocean (group i) and the mainland (group ii) in the following sections (more details can be found in Sect. 3.4 and Table S1). The average value of $k_{\mathrm{a}}$ at Yokohama $\left(0.005 \pm 0.005 \mathrm{~s}^{-1}\right)$ was much higher than that found for Kyoto city $\left(0.0017 \pm 0.0015 \mathrm{~s}^{-1}\right)$ (with calculated $p<0.05$; Mann-Whitney), this may due to many differences in aerosol properties in Kyoto and Yokohama city. We list some of them as follows: 1) mass composition, the aerosols in the coast city tend to contain more sea salts thus increased $\left.k_{\mathrm{a}}, 2\right)$ particle

253 size distribution, smaller particles tending to yield higher $\gamma$ values than larger particles owing to the limitation of gas phase diffusion is smaller with micrometer particles, and the distribution of depleting species (e.g., transition metal ions) are mostly distributed in accumulation mode of aerosol, 3) the water content and the metal concentrations, this will highly influence the $\mathrm{HO}_{2}$ uptake capacity of the ambient aerosols. However, the average $\mathrm{HO}_{2}$ uptake coefficient onto ambient aerosols $(\gamma)$ in Yokohama $(\sim 0.23)$ was comparable with previous measured ( 0.24-0.25) (Zhou et al., 2019b; Taketani et al., 2012) and modeled ( 0.20) values (Stadtler et al., 2018; Jacob, 2000). The large standard deviation $( \pm 0.21,1 \sigma)$ of the values along with the measurement time may be due to the instantaneously changed chemical and physical properties of ambient aerosols, indicating that a large bias may exist if a constant $\gamma$ value is used for modeling.

$263 \quad 3.2$ Bulk chemical composition of ambient aerosols 

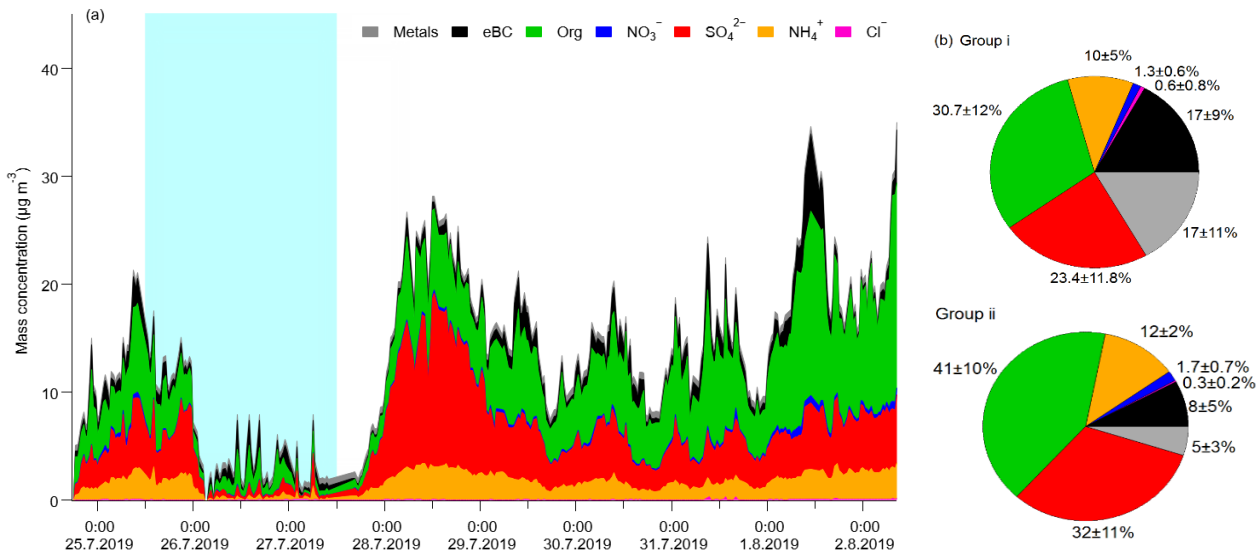

Figure 2: (a) Concentrations of non-refractory chemical components plus eBC in Yokohama, Japan (July 24 to August 02, 2019). The blue shaded area represents group i from coast and the remaining areas represent group ii from mainland. (b) Average contribution fractions of different chemical components of groups i and ii.

Figure $2 \mathrm{a}$ shows the time series of the mass concentrations of $\mathrm{OA}, \mathrm{SO}_{4}{ }^{2-}, \mathrm{NO}_{3}{ }^{-}, \mathrm{NH}_{4}{ }^{+}, \mathrm{Cl}^{-}$, and eBC in

$\mathrm{PM}_{1}$ in Yokohama from July 24 to August 02,2019 , which is $\sim 1.5$ days less than for the LFP-LIF data.

During this period, $\mathrm{PM}_{1}$ ranged from $\sim 1$ to $35 \mu \mathrm{g} \mathrm{m}^{-3}$ (average $\approx 13 \mu \mathrm{g} \mathrm{m}^{-3}$ ) and was dominated by OA,

$\mathrm{SO}_{4}{ }^{2-}$, and $\mathrm{NH}_{4}{ }^{+}$, with contributions of $39 \pm 11 \%, 30 \pm 12 \%$, and $12 \pm 4 \%$, respectively; these were

followed by eBC and metals, with contributions of $10 \pm 7 \%$ and $8 \pm 8 \%$, respectively. $\mathrm{Cl}^{-}$contributed

$<1 \%$ in both groups, which is similar to that reported for an urban area in winter in Bern (Switzerland)

(Zhou et al., 2019a). However, $\mathrm{NO}_{3}{ }^{-}$contributed much less $(\sim 2 \pm 0.7 \%)$ compared with that reported for Bern $(\sim 19 \pm 4 \%)$, which may be due to the reverse reaction of $\mathrm{NH}_{4} \mathrm{NO}_{3}$ converting to $\mathrm{HNO}_{3}$. Since

Yokohama is a coastal city, and $\mathrm{HNO}_{3}$ is easy vaporized in summer, gaseous $\mathrm{HNO}_{3}$ may sink with sea salt particles by forming $\mathrm{NaNO}_{3}$ through heterogeneous reactions (Finlayson-Pitts and Pitts, 2000).

Figure $2 b$ shows the average contribution fractions of different components of group $i$ and group ii. The main differences in the components between these two groups are the fractions of $\mathrm{OA}, \mathrm{BC}, \mathrm{SO}_{4}{ }^{2-}$, and metals. The OA fraction was $\sim 1.8$ and $\sim 8.4$ times higher than that for the metals in groups $\mathrm{i}$ and ii, respectively. As OA can cover the surface of the particles and thereby decrease $\gamma$ (Lakey et al., 2016a; Takami et al., 2013), the difference between the OA and metal fractions in these two groups may partially explain the much higher $\gamma$ values of group i (vs. group ii). Previous studies have shown quite 

in contrast to the results obtained here. This may due to the much higher fraction of eBC in group $\mathrm{i}$ (vs. group ii) may also provide active sites thus facilitating the physical uptake of $\mathrm{HO}_{2}$. We also observed slightly higher $\mathrm{Cl}^{-}$and $\mathrm{BC}$ fraction in group i (from ocean) than that of group ii (from mainland), which may due to the effects of sea salt and the ship emissions, respectively. From the average diurnal patterns (Figs. S5 and S6), the trends in $k_{\mathrm{a}}$ follow the trends in chemical composition, whereas $\gamma$ shows a contrasting trend with both variables in both groups. For group ii, $\mathrm{SO}_{4}{ }^{2-}$ and $\mathrm{OA}$ exhibited higher values whereas $\gamma$ exhibited lower values during the daytime than those during nighttime, indicating that secondary aerosol formation resulting from photochemical reactions may decrease $\gamma$. To identify the influence of each individual chemical component of ambient aerosol on $k_{\mathrm{a}}$ and $\gamma$, we further performed correlation matrix analysis.

\subsection{Influence of individual chemical components of ambient aerosol on $k_{\mathrm{a}}$ and $\gamma$}

For the ambient aerosol with multiple components, $k_{\mathrm{a}}$ and are influenced by many factors, and those factors also have mutual effects to each other, for example, the transition metal $\mathrm{Cu}$ and $\mathrm{Fe}$ contained in ambient aerosols can be chelated by organics (Lakey et al., 2016b). The direct correlations between transition metals and $\gamma$ may give us some hints about the interactions of different chemical components in ambient aerosols and their effects to $\gamma$. Therefore, we produced a Pearson correlation matrix of all the testing chemical composition factors in Yokohama city. To exclude the effects of the different fractions of chemical components in groups i and ii, the bootstrap method, which is based on the creation of replicate the inputs by perturbing the original data through resampling, was employed. The resampling was performed by randomly reorganizing the rows of the original time series such that some rows of the original data were present several times while other rows were removed. The final results were obtained by running the data for 1000 bootstrap replicates. The average values of these 1000 bootstrap replicates are listed in Fig. 3. 


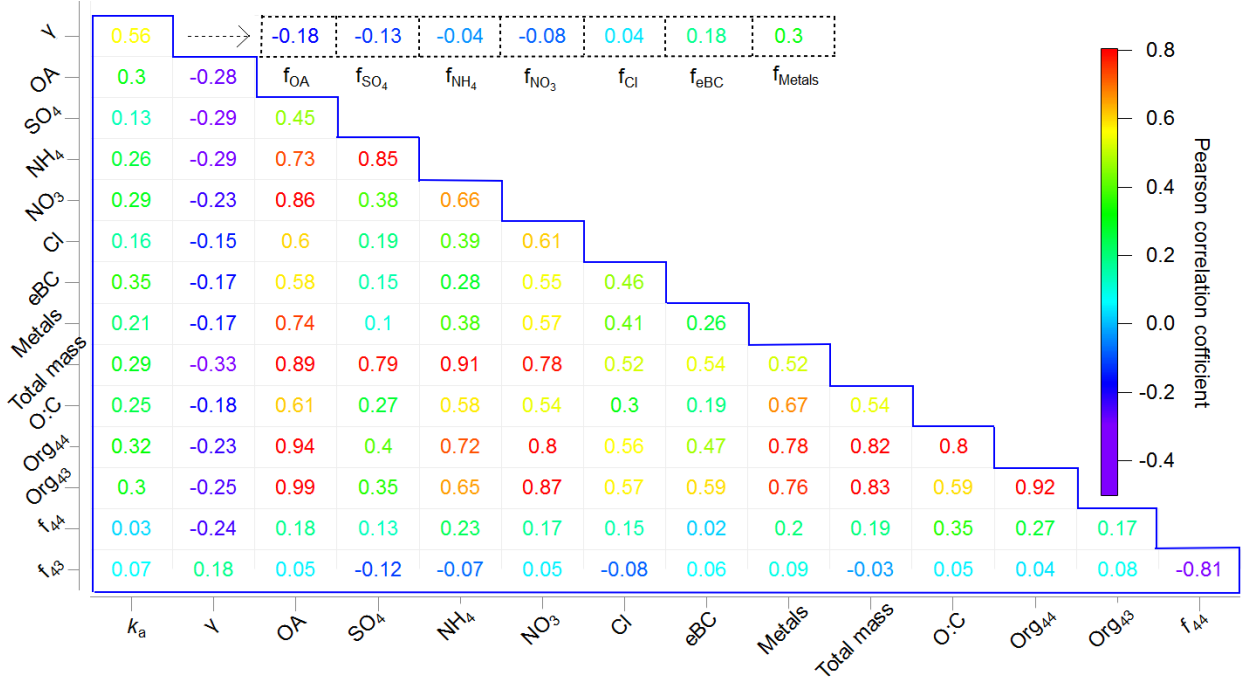

Figure 3: Correlation matrix showing Pearson's $r$ values for the chemical compositions, $k_{\mathrm{a}}$, and $\gamma$ during the corresponding measurement periods (in the blue box), as well as the Pearson's $r$ values for the chemical composition fraction $i$ (represented as $f i, i=\mathrm{OA}, \mathrm{SO}_{4}{ }^{2-}, \mathrm{NH}_{4}{ }^{+}, \mathrm{NO}_{3}{ }^{-}, \mathrm{Cl}^{-}, \mathrm{eBC}$, and metals) and $\gamma$ (in the dashed line box).

Most of the chemical components had strong or moderate Pearson correlation coefficients with each

other (Fig. 3), although $k_{\mathrm{a}}$ and $\gamma$ showed only a moderate correlation with each other (0.56). As $\gamma$ can be correlated with the qualitative, rather than quantitative, properties of the aerosols, we further investigated the Pearson's r values between the chemical composition fractions and $\gamma$. The results show that $k_{\mathrm{a}}$ was positively correlated with total mass and the individual chemical components, whereas $\gamma$ showed only a weak positive correlation with fmetals $(0.30)$ and $f_{\mathrm{eBC}}(0.18)$. This indicates that the metals may act as a catalyst, thus accelerating the depletion of $\mathrm{HO}_{2}$ (Mao et al., 2013a) (chemical reaction), and that $\mathrm{BC}$ may provide the active sites for $\mathrm{HO}_{2}$ radical interaction with ambient aerosols (physical uptake). The very weak correlation of $\gamma$ with $f_{\mathrm{Cl}^{-}}(0.04)$ may be related to $\mathrm{Cl}^{-}$chemistry, for example, $\mathrm{HO}_{2}(\mathrm{~g})$ can react with $\mathrm{NaCl}(\mathrm{g})$ and produce $\mathrm{NaOH}$ and $\mathrm{Cl}_{2}(\mathrm{~g})$, thus cause a decrease in the $\mathrm{HO}_{2}$ concentration, which in turn indirectly effects $\gamma$ (Remorov et al., 2002). Interestingly, when considering the Org44 and Org43 fractions in total OA separately, $\gamma$ is positively correlated with $f_{43}$ $(0.18)$ but negatively correlated with $f_{44}(-0.24)$. This is consistent with the conclusion from Lakey et al. (2016b), i.e., that more oxidized organic aerosols tend to be highly viscous and thus decrease $\mathrm{HO}_{2}$ uptake coefficients (Lakey et al., 2016b). In summary, $\gamma$ was dominated by the free forms of transition 
$353 \frac{1}{\gamma^{\mathrm{TMI}}}=\frac{1}{\alpha^{\mathrm{HO}_{2}}}+\frac{\omega}{H_{e f f} R T \sqrt{k^{I} D_{a q} Q^{\prime}}}$

$$
\frac{1}{\gamma^{\mathrm{TMI}}}=\frac{1}{\alpha^{\mathrm{HO}_{2}}}+\frac{\omega}{H_{e f f} R T \sqrt{k^{I} D_{a q} Q^{\prime}}}
$$

metals that can act as catalysts of $\mathrm{HO}_{2}$ uptake onto ambient aerosols, and was indirectly affected by chemical components that might alter the properties of ambient aerosols, e.g., oxygenated OA can cover the aerosol surface and alter the viscosity of ambient aerosols, thereby decreasing $\gamma$ (Lakey et al., 2016a; Lakey et al., 2016b; Takami et al., 2013), whereas BC may provide active sites and thereby increase $\gamma$ though physical uptake. This is further confirmed by the classification of the air masses, i.e., the air mass from the ocean (group i), which had a higher $\mathrm{HO}_{2}$ uptake capacity, contained less OA and more metals than that from mainland Japan (group ii). We further compared the measured $\gamma$ values with the modeled $\gamma$ values using previously proposed mechanisms, as shown below.

\subsection{Possible mechanism of $\mathrm{HO}_{2}$ uptake onto ambient aerosols}

Two mechanisms of $\mathrm{HO}_{2}$ uptake onto aqueous ambient aerosols have been proposed, for which equations have been derived from a previous study (Thornton et al., 2008): (i) $\mathrm{HO}_{2}$-only chemistry and (ii) chemistry with transition metals playing a role. In this study, the liquid content of the total ambient aerosol mass ranged from $70 \%$ to $88 \%$, as obtained from the ISORROPIA-II model. As the solubility of Fe is rather small in ambient aerosol, the reaction rates of $\mathrm{Fe} / \mathrm{Mn}$ for liquid phase $\mathrm{HO}_{2}$ in aerosol is 100 times slower than it is for $\mathrm{Cu}$, thus the influence of $\mathrm{Fe}$ and $\mathrm{Mn}$ on $\mathrm{HO}_{2}$ uptake can be neglected compared to $\mathrm{Cu}$ or scaled as equivalent $\left[\mathrm{Cu}^{2+}\right.$ (Fang et al., 2017; Hsu et al., 2010; Baker and Jickells, 2006; Oakes et al., 2012; Song et al., 2020), therefore, we use the soluble $\mathrm{Cu}$ as surrogate for transition metals in ambient aerosols to assess the influence of transition metals to $\gamma$ in ambient aerosols. The $\mathrm{Cu}$ solute mass fraction in the liquid content of the ambient aerosols was estimated as $(3.5-30) \times 10^{-4} \mathrm{~mol}$ $\mathrm{L}^{-1}$ according to our offline filter test (Sect. 2.2), and the activity coefficient for total $\mathrm{Cu}$ was assumed to be 0.1 (upper limit) based on a study of $\left(\mathrm{NH}_{4}\right)_{2} \mathrm{SO}_{4}$ particles at $68 \% \mathrm{RH}$ (Ross and Noone, 1991). Using copper ions as a surrogate metal for transition metal ions (TMIs), the potential $\mathrm{HO}_{2}$ loss onto aqueous ambient aerosols via mechanisms involving TMIs was estimated as (Hanson et al., 1994):

where $\alpha^{\mathrm{HO}_{2}}$ is the mass accommodation coefficient of $\mathrm{HO}_{2}, \omega$ is the mean $\mathrm{HO}_{2}$ molecular speed (cm s $\left.{ }^{1}\right), H_{\text {eff }}$ is the effective Henry's Law coefficient, $\mathrm{R}$ is the gas constant $\left(\mathrm{J} \mathrm{K}^{-1} \mathrm{~mol}^{-1}\right)$, and $T$ the temperature 
(K). $k^{\mathrm{I}}$ is the pseudo-first-order rate constant equal to $k_{\mathrm{TMI}}^{\mathrm{II}}[\mathrm{TMI}]$, where $k_{\mathrm{TMI}}^{\mathrm{II}}$ is the second order rate constant for aqueous phase reaction with $\mathrm{HO}_{2} / \mathrm{O}_{2}{ }^{-}$and TMI. $Q^{\prime}$ accounts for aqueous-phase diffusion limitations and is expressed as

$Q^{\prime}=\left[\operatorname{coth}(q)-\frac{1}{q}\right] ; q=r_{p} \sqrt{\frac{k^{\mathrm{I}}}{D_{a q}}}$

Table S1 shows more details of the parameters used for modeling. $\gamma^{\mathrm{TMI}}$ with $\alpha^{\mathrm{HO}_{2}}=0.2$ (typically for organics) and 0.5 (typically for inorganics as explained in Table S1) are plotted in Fig. 4a along with the measured $\gamma$ values; the much lower variation of the modeled values may due to the low time resolution $(\sim 2$ days) of $[\mathrm{Cu}]$. The measured $\gamma$ values (averaged value: $\sim 0.23$ ) are significantly lower than the modelled $\gamma^{\mathrm{TMI}}$ with $\alpha^{\mathrm{HO}_{2}}=0.5$ (averaged value: $\sim 0.32$ ), but significantly higher than the modelled $\gamma^{\mathrm{TMI}}$ with $\alpha^{\mathrm{HO}_{2}}=0.2$ (averaged value: $\sim 0.16$ ), both with calculated $p<0.05$ (t-test), indicating that the chemical components may be internally mixed, as proposed by Takami et al. (2013), which influences the aerosol surface tension and the activity of the free form of the copper ion (i.e., OA and BC) to constrain $\gamma^{\text {TMI}}$; however, this is not considered in this model. No linear correlation was found between $\gamma^{\mathrm{TMI}}$ and $\gamma$. Further classification of measured $\gamma \geq 0.4$ and $\gamma<0.4$ shows that $\gamma^{\mathrm{TMI}}$ has a weak correlation with measured $\gamma$ values when $\gamma \geq 0.4$ (Fig. S7), which may due to the higher fraction of metals in the total mass at measured $\gamma \geq 0.4$ $(\sim 12 \%)$ than at $<0.4(\sim 7 \%)$; therefore, the impact of the other chemical components is much lower. The $\gamma$ values obtained here are comparable with those in previous ambient aerosol studies (Taketani et al., 2008; Zhou et al., 2019b) (Fig. 5b). When compare with single-compound aerosols obtained from laboratory studies, $\gamma$ values were generally higher than the $\mathrm{HO}_{2}$ uptake coefficients onto organic species (Lakey et al., 2015), soot particles (Bedjanian et al., 2005), and the dry state of inorganic aerosols (i.e., $\left(\mathrm{NH}_{4}\right)_{2} \mathrm{SO}_{4}, \mathrm{NaCl}$, and $\mathrm{H}_{2} \mathrm{SO}_{4}$ ), but comparable or lower than aqueous and copper-doped aqueous phases of inorganic species (Fig. 5b) (George et al., 2013; Lakey et al., 2016b; Taketani et al., 2008; Thornton and Abbatt, 2005). This may indicate the collective effects of the individual chemical components of ambient aerosols to $\gamma$, and the significant influence of RH to aerosol states of single-component particles thus their $\mathrm{HO}_{2}$ uptake coefficients. 


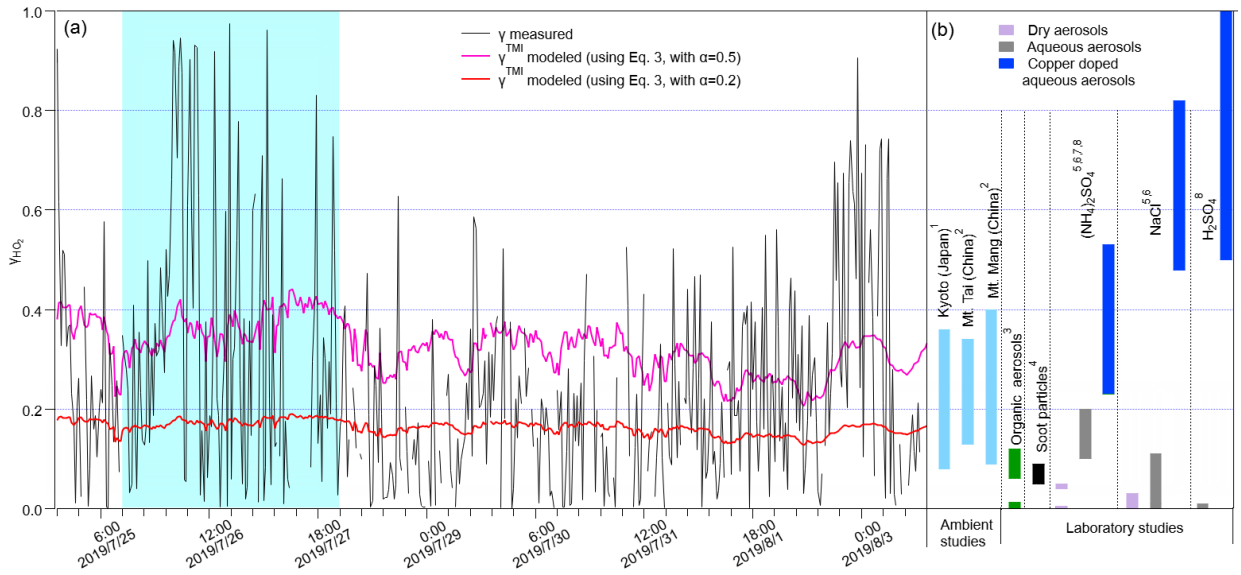

Figure 4: (a) Measured and modeled $\gamma$ values along with measurement time. The blue shaded area represents group i; the remaining areas represent group ii. (b) $\mathrm{HO}_{2}$ uptake coefficients onto different types of aerosol obtained from ambient and laboratory studies, the numbers indicate the related references from which the data were obtained: 1 . Zhou et al., 2019b; 2. Taketani et al., 2012; 3. Lakey et al, 2015; 4. Bedjanian et al., 2005; 5. Taketani et al., 2008; 6. George et al., 2013; 7. Lakey et al., 2016b; 8. Thornton and Abbatt, 2005.

Other studies have shown that $\gamma$ is strongly negatively temperature dependent (Remorov et al., 2002; Mao et al., 2010; Cooper and Abbatt, 1996; Hanson et al., 1992; Thornton and Abbatt, 2005; Gershenzon et al., 1995). Here, RH and $T$ were stabilized by the VACES-LFP-LIF system, as compared with those in ambient air (Fig. S8). We noticed that $k_{\mathrm{a}}$ and $\gamma$ showed no dependence on RH and $T$ in the reaction cell (see Fig. S9), indicating that the instantaneous change of RH and $T$ may not be dominating factors in terms of the variation of $k_{\mathrm{a}}$ and $\gamma$ with measurement time. This suggests that the individual chemical components and physical properties of ambient aerosols may dominate $\gamma$ variation during field campaign; both the metal-catalyzed reactions and the chemical components and their states should be considered to yield more accurate $\gamma$ values. Results obtained here are in accordance with previous results on correlations between particulate $\mathrm{H}_{2} \mathrm{O}_{2}$ (which can be formed by the uptake of $\mathrm{HO}_{2}$ ) and coarse particulate transition metals (Wang et al., 2010). Using an offline methodology to investigate the influence of $\mathrm{RH}$ and $T$ by maintaining constant experimental conditions or chemical compositions will be the subject of future work.

\subsection{Influence of the physical properties of ambient aerosols on $\boldsymbol{k}_{\mathrm{a}}$ and $\gamma$}

$\mathrm{HO}_{2}$ heterogeneous loss rates are driven by the different particle sizes of different aerosol types (i.e., urban ambient aerosols and marine aerosols)(Morita et al., 2004; Guo et al., 2019; Jacob, 2000). In this 

Identifying the fractional contributions of aerosols in different particle size ranges to $k_{\mathrm{a}}$ and $\gamma$ is highly desirable in terms of understanding their influence. However, it seems that high $\gamma$ values (>0.8) occur when the surface area is $<2 \times 10^{-6} \mathrm{~cm}^{2} \mathrm{~cm}^{-3}$ and the mean particle diameter is $<110 \mathrm{~nm}$. This is in accordance with a previous study showing that aerosols yield the highest fractional contribution to the total heterogeneous loss rate of $\mathrm{HO}_{2}$ radicals of size $<0.1 \mu \mathrm{m}$ (Morita et al., 2004) and that the mass accommodation process plays the determining role for small and medium sized aerosols in controlling $\mathrm{HO}_{2}$ uptake. Guo et al. (2019) states the $\mathrm{HO}_{2}$ radicals experience less loss upon diffusion onto large aerosols than do small droplets due to dilution effects make the larger aerosols having lower depleting species concentrations $\left(\mathrm{Cu}^{2+}\right)$. However, this was based on the assumption that the total mass of $\mathrm{Cu}^{2+}$ is constant during the hygroscopic growth of particles which is not always true in the ambient conditions. Further studies about $\mathrm{Cu}^{2+}$ content in particles with different size distribution are needed to fully understand the result here.

\subsection{Significance of $k_{a}$ to $\mathrm{O}_{3}$ formation potential}

In urban atmosphere, $\mathrm{XO}_{2}\left(=\mathrm{HO}_{2}+\mathrm{RO}_{2}\right)$ fate is important to the photochemical production of ozone $\left(\mathrm{P}\left(\mathrm{O}_{3}\right)\right)$. Here, the loss rates of $\mathrm{XO}_{2}$ due to three factors were compared: (i) uptake onto the ambient aerosols $\left(L_{\mathrm{P}-\mathrm{XO}_{2}}\right.$ in Eq. 5), since no experiment or reference available for $\mathrm{RO}_{2}$ uptake onto ambient particles, we assume the $\mathrm{RO}_{2}$ reactivities caused by its interaction with ambient aerosols were the same as $k_{\mathrm{a}}$, (ii) $\mathrm{XO}_{2}$ self-reactions $\left(L_{\mathrm{R}-\mathrm{XO}_{2}}\right.$ in Eq. 6), and (iii) reaction with $\mathrm{NO}\left(L_{\mathrm{N}-\mathrm{XO}_{2}}\right.$ in Eq. 7$)$, which can produce $\mathrm{NO}_{2}$, a precursor of $\mathrm{O}_{3}$; therefore Eq. 7 can also be regarded as $\mathrm{P}\left(\mathrm{O}_{3}\right)$.

$L_{\mathrm{R}-\mathrm{XO}_{2}}=2 *\left(k_{\mathrm{HO}_{2}-\mathrm{HO}_{2}}\left[\mathrm{HO}_{2}\right]^{2}+k_{\mathrm{HO}_{2}-\mathrm{RO}_{2}}\left[\mathrm{HO}_{2}\right]\left[\mathrm{RO}_{2}\right]\right)$

$L_{\mathrm{NO}-\mathrm{XO}_{2}}=k_{\mathrm{NO}-\mathrm{XO}_{2}}[\mathrm{NO}]\left[\mathrm{XO}_{2}\right]=\mathrm{P}\left(\mathrm{O}_{3}\right)$

where $k_{\mathrm{HO}_{2}-\mathrm{HO}_{2}}$ and $k_{\mathrm{HO}_{2}}-\mathrm{RO}_{2}$ are the second-order rate constants of $\mathrm{HO}_{2}$ self-reaction and its reaction with $\mathrm{RO}_{2}$, respectively. $k_{\mathrm{NO}-\mathrm{HO}_{2}}$ is the second-order rate constant of the reaction of $\mathrm{HO}_{2}$ with NO. The $\mathrm{HO}_{2}$ concentration was estimated from $\mathrm{O}_{3}$ concentration using the method described by Kanaya et al., 
(2007a). The $\mathrm{RO}_{2}$ concentration is then estimated by assuming a steady state of $\mathrm{HO}_{2}$ in the $\mathrm{HO}_{\mathrm{x}}$ cycle; the reaction rates of $\mathrm{HO}_{2}$ radicals are approximated as 0 :

$$
\begin{aligned}
& \frac{d\left[\mathrm{HO}_{2}\right]}{d t}=P_{\mathrm{HO}_{2}}-L_{\mathrm{HO}_{2}}=k_{\mathrm{CO}-\mathrm{OH}}[\mathrm{OH}][\mathrm{CO}]+k_{\mathrm{H}_{2} \mathrm{CO}-\mathrm{OH}}[\mathrm{OH}]\left[\mathrm{H}_{2} \mathrm{CO}\right]+k_{\mathrm{NO}_{-} \mathrm{RO}_{2}}\left[\mathrm{RO}_{2}\right][\mathrm{NO}]- \\
& 2 k_{\mathrm{HO}_{2}-\mathrm{HO}_{2}}\left[\mathrm{HO}_{2}\right]\left[\mathrm{HO}_{2}\right]-k_{\mathrm{HO}_{2}-\mathrm{RO}_{2}}\left[\mathrm{HO}_{2}\right]\left[\mathrm{RO}_{2}\right]-k_{\mathrm{NO}_{-} \mathrm{HO}_{2}}\left[\mathrm{HO}_{2}\right][\mathrm{NO}]-k \mathrm{a}\left[\mathrm{HO}_{2}\right]=0
\end{aligned}
$$

where $k_{\mathrm{CO}-\mathrm{OH}}$ and $k_{\mathrm{H}_{2} \mathrm{CO}-\mathrm{OH}}$ are the second-order rate constants of the reactions of $\mathrm{CO}$ and $\mathrm{H}_{2} \mathrm{CO}$ with $\mathrm{OH}$, respectively. The different $\mathrm{XO}_{2}$ loss rates described in Eqs. 5-7, along with the measurement times, are shown in Fig. 5a. Generally, $L_{\mathrm{P}-\mathrm{XO}_{2}}$ is much greater than $L_{\mathrm{R}-\mathrm{XO}_{2}}$, indicating that the $\mathrm{XO}_{2}$ taken up by ambient aerosols will compete with the $\mathrm{XO}_{2}$ self-reaction, thus influencing $\mathrm{XO}_{2}$ concentration. However, such an influence may have a negligible impact on $\mathrm{P}\left(\mathrm{O}_{3}\right)$ because $L_{\mathrm{P}-\mathrm{XO}_{2}}$ is tens of thousands times lower than $L_{\mathrm{NO}-\mathrm{XO}_{2}}$ owing to the relatively high NOx concentration in Yokohama. We further tested the impact of $L_{\mathrm{P}-\mathrm{XO}_{2}}$ on ozone formation sensitivity regime, according to the method proposed by Sakamoto et al. (2019), in which $\mathrm{L}_{\mathrm{N}} / \mathrm{Q}$ is used as a new indicator:

$\frac{L_{N}}{Q}=\frac{1}{1+\left(\frac{\left(2 k_{\mathrm{R}}\left[\mathrm{XO}_{2}\right]+k_{a^{\prime}}\right) k_{\mathrm{OH}-\mathrm{VOCs}}[\mathrm{VOCs}]}{\left.\left(1-\alpha^{\prime}\right) k_{\mathrm{NO}-\mathrm{HO}_{2}}[\mathrm{NO}] k_{\mathrm{OH}-\mathrm{NO}_{2}\left[\mathrm{NO}_{2}\right]}\right)}\right.}$

where $k_{\mathrm{OH}-\mathrm{VOCs}}$ and $k_{\mathrm{OH}-\mathrm{NO}_{2}}$ are the second-order rate constants of the reactions of $\mathrm{OH}$ with VOCs and $\mathrm{NO}_{2}$, respectively. $k_{\mathrm{NO}-\mathrm{HO}_{2}}$ is the second-order rate constant of the reaction of $\mathrm{NO}$ with $\mathrm{HO}_{2} . \alpha^{\prime}$ is the proportion of $\mathrm{RO}_{2}$ in $\mathrm{XO}_{2} . \mathrm{L}_{\mathrm{N}}$ is the $\mathrm{OH}$ radical loss rate through its reaction with $\mathrm{NO}_{2}$. $(=$ $\left.k_{\mathrm{OH}-\mathrm{NO}_{2}}[\mathrm{OH}]\left[\mathrm{NO}_{2}\right]\right)$, and Q is the total loss of the HOx radicals in the HOx cycle reaction $\left(=L_{\mathrm{N}}+\right.$ $\left.L_{\mathrm{P}-\mathrm{XO}_{2}}+L_{\mathrm{R}-\mathrm{XO}_{2}}\right)$. The regime transition point can be expressed as ${\frac{L_{\mathrm{N}}}{Q_{\text {transition }}}}=(1-\chi) \frac{1}{2}+\chi \frac{1}{3}$

where $\chi=L_{\mathrm{P}-\mathrm{XO}_{2}} /\left(L_{\mathrm{P}-\mathrm{XO}_{2}}+L_{\mathrm{R}-\mathrm{XO}_{2}}\right)$. The results indicate that both $\mathrm{L}_{\mathrm{N}} / \mathrm{Q}$ and $\mathrm{L}_{\mathrm{N}} / \mathrm{Q} \_$without_aerosol (calculated with and without including $k_{a}{ }^{\prime}$ in Eq. 9, respectively) were higher than $\mathrm{L}_{\mathrm{N}} / \mathrm{Q} \_$transition, indicating that ozone formation was VOC-sensitive throughout the campaign and that the aerosol uptake of $\mathrm{XO}_{2}$ (ka') showed no impact on the $\mathrm{O}_{3}$ formation regime (see Fig. 5, here we only consider the daytime, when photochemical reactions occur). The plots of $\mathrm{L}_{\mathrm{N}} / \mathrm{Q}$ and $\mathrm{L}_{\mathrm{N}} / \mathrm{Q} \_$without_aerosol as a 

in this section are shown in Fig. S12.
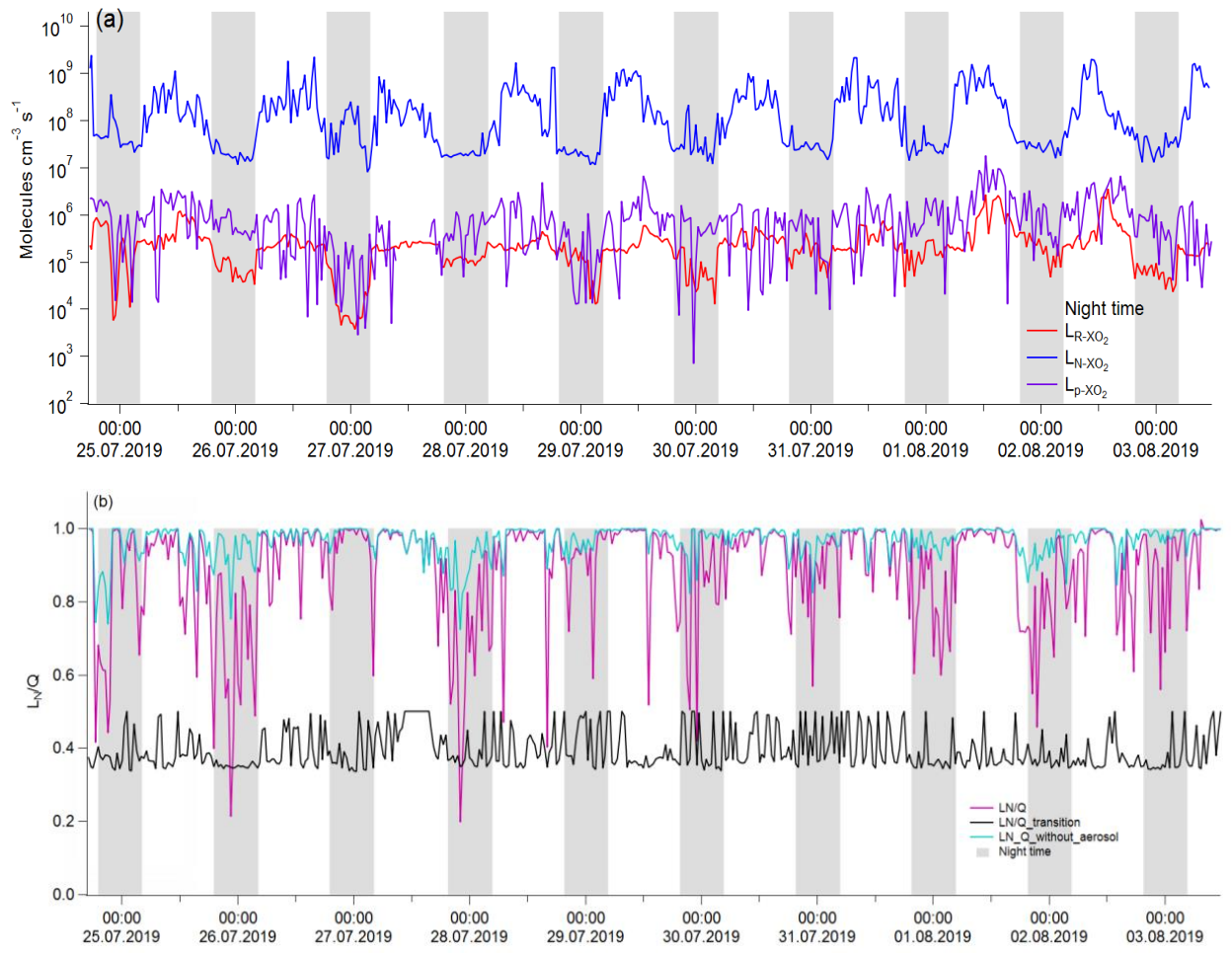

Figure 5: Temporal variations in (a) $\mathrm{HO}_{2}$ radical loss rates and (b) $\mathrm{L}_{\mathrm{N}} / \mathrm{Q}$ (red line) and the regime transition threshold ( $\mathrm{L}_{N} / \mathrm{Q}_{-}$transition, black line) used to assess the ozone sensitivity regime. The gray shaded areas represent nighttime (from National Astronomical Observatory of Japan) and are not discussed herein.

\section{Conclusions}

This study used a reliable online methodology to investigate $\mathrm{HO}_{2}$ uptake kinetics onto in situ ambient aerosols (i.e., $\mathrm{HO}_{2}$ reactivity of ambient aerosols $k_{\mathrm{a}}$ and $\mathrm{HO}_{2}$ uptake coefficients $\mathrm{y}$ ) and discussed the impacting factors on such processes, i.e., chemical compositions and physical properties of ambient aerosols and experimental conditions. $k_{\mathrm{a}}$ ranged between $0.001 \mathrm{~s}^{-1}\left(25^{\text {th }}\right.$ percentile $)$ and $0.005 \mathrm{~s}^{-1}\left(75^{\text {th }}\right.$

477 percentile), with an average value of $0.005 \pm 0.005 \mathrm{~s}^{-1}$. The corresponding $\gamma$, ranged from $0.05\left(25^{\text {th }}\right.$ 

measured ( 0.24-0.25) (Zhou et al., 2019b; Taketani et al., 2012) and modeled ( 0.20) values (Stadtler et al., 2018; Jacob, 2000). We noticed that $k_{\mathrm{a}}$ and $\gamma$ showed no dependence on RH and $T$ in the reaction cell in this study, indicating that the instantaneous change of RH and $T$ may not be dominating factors in terms of the variation of $k_{\mathrm{a}}$ and $\gamma$ with measurement time, and the large standard deviation of the $\gamma$ values along with the measurement time $( \pm 0.21,1 \sigma)$ may be due to the instantaneously changed chemical and physical properties of ambient aerosols, a large bias may exist if a constant $\gamma$ value is used for modeling.

We found that the individual chemical components of ambient aerosols may have collective effects of to $\gamma$, through the analyses of 1) separating the air masses into two groups, group i from the ocean and group ii from mainland Japan; 2) the average diurnal patterns; 3) the correlation matrix analysis of each individual chemical component of ambient aerosol with $\gamma$, and 4) the modeling studies using previously proposed mechanisms. All these effects clearly indicating that the transition metals contained in ambient aerosols may act as a catalyst, thus accelerating the depletion of $\mathrm{HO}_{2}$, however, they can be chelated by OA. OA can also cover the aerosol surface and alter the viscosity of ambient aerosols, thereby decreasing $\gamma$, and that more oxidized organic aerosols tend to be highly viscous and thus decrease $\mathrm{HO}_{2}$ uptake coefficients. Results obtained here are in accordance to previous laboratory and modeling studies (Mao et al., 2013a; Lakey et al., 2016b; Lakey et al., 2016a; Takami et al., 2013; Thornton et al., 2008; Hanson et al., 1994), and that the chemical components of ambient aerosols may be internally mixed, as proposed by Takami et al. (2013), which influences the aerosol surface tension and the activity of the free form of the copper ion (i.e., OA and BC) to constrain $\gamma$. In contrast to previous studies saying that BC may shrink $\mathrm{HO}_{2}$ losses onto ambient aerosols (Saathoff et al., 2001; Macintyre and Evans, 2011; Bedjanian et al., 2005), we found $\mathrm{BC}$ positively correlated with $\mathrm{HO}_{2}$ uptake coefficients (0.18), this may be owing to $\mathrm{BC}$ can provide active sites thus facilitating the physical uptake of $\mathrm{HO}_{2}$. Here, we observed higher $\gamma$ values $(>0.8)$ when the mean particle diameter is $<110 \mathrm{~nm}$, identifying the fractional contributions of aerosols in different particle size ranges to $k_{\mathrm{a}}$ and $\gamma$ is highly desirable in terms of understanding their influence. 

dominate $\gamma$ variation during field campaign; both the metal-catalyzed reactions and the chemical components and their states should be considered to yield more accurate $\gamma$ values. In future work, improvements to the time-resolution of metal measurements are needed for more precise analysis. For more detailed investigations of $\mathrm{HO}_{2}$ uptake mechanisms, an offline methodology that can maintain constant chemical compositions or other experimental conditions (such as RH and $T$ ) will be useful.

511 The $\mathrm{HO}_{2}$ loss onto ambient aerosols was identified to have a negligible impact on the $\mathrm{O}_{3}$ production rate and formation regime owing to the high $\mathrm{NO}_{\mathrm{X}}$ concentrations in Yokohama. This process may play a more important role in $\mathrm{O}_{3}$ formation under low $\mathrm{NOx}$ and high aerosol loading conditions. The results help us to understand the impacts of $\mathrm{HO}_{2}$ uptake kinetics on chemical transformations in troposphere.

\section{Appendix:}

Air mass directions (Figure S1), measurement strategy (Figure S2), a technique combined laser-flash photolysis with laser-induced fluorescence (LFP-LIF), the enrichment of the ambient aerosols, $\mathrm{HO}_{2}$ reactivity of ambient air, correction of gas-phase diffusion for $\mathrm{HO}_{2}$ uptake coefficient, $\mathrm{HO}_{2}$ reactivity of ambient gas phase $\left(k_{\mathrm{g}}\right)$, examples of $\mathrm{HO}_{2}$ decay profiles (Figure $\mathrm{S} 3$ ), $\mathrm{HO}_{2}$ reactivity calibration with different $\mathrm{NO}_{2}$ concentrations (Figure $\mathrm{S} 4$ ), diurnal trends in individual chemical components of ambient aerosols (Figure S5), diurnal trends in $k_{\mathrm{a}}$ and $\gamma$ (Figure S6), correlations between measured and modeled $\gamma$ (Figure S7), time series of the averaged RH and $T$ in ambient air and the reaction cell (Figure S8), dependence of $k_{\mathrm{a}}$ and $\gamma$ on $\mathrm{RH}$ in reaction cell (Figure S9), dependence of $k_{\mathrm{a}}$ and $\gamma$ on mean particle diameter (Figure S10), dependence of day time LN/Q and LN/Q_without_aerosol on [NO] (Figure $\mathrm{S} 11$ ), profiles of key factors determining $\mathrm{XO}_{2}$ loss rates and $\mathrm{P}\left(\mathrm{O}_{3}\right)$ sensitivity (Figure $\mathrm{S} 12$ ), summary of equations and values used for $\gamma$ modeling (Table S1), summary of equations and values used for $\mathrm{XO}_{2}$ $\left(=\mathrm{HO}_{2}+\mathrm{RO}_{2}\right)$ loss and $\mathrm{O}_{3}$ formation sensitivity regime (Table $\left.\mathrm{S} 1\right)$.

\section{Author contribution}




\section{Competing interests}

534 The authors declare that they have no conflict of interest.

535

536

\section{Data availability}

Data supporting this publication are available upon request for the corresponding author (junzhou@jnu.edu.cn).

\section{Acknowledgments}

This work was supported by the Japan Society for the Promotion of Science (JSPS) KAKENHI Grant Numbers JP16H06305, JP19H04255. Many thanks to Yokohama Environmental Science Research Institute utility during the campaign.

\section{References}

Baker, A. R., and Jickells, T. D.: Mineral particle size as a control on aerosol iron solubility, Geophys. Res. Lett., 33, 10.1029/2006GL026557, 2006.

Bedjanian, Y., Lelièvre, S., and Le Bras, G.: Experimental study of the interaction of $\mathrm{HO}_{2}$ radicals with soot surface, Phys. Chem. Chem. Phys., 7, 334-341, 10.1039/B414217A, 2005.

Chen, G., Davis, D., Crawford, J., Heikes, B., O'Sullivan, D., Lee, M., Eisele, F., Mauldin, L., Tanner, D., Collins, J., Barrick, J., Anderson, B., Blake, D., Bradshaw, J., Sandholm, S., Carroll, M., Albercook, G., and Clarke, A.: An assessment of HOx chemistry in the tropical pacific boundary layer: comparison of model simulations with observations recorded during PEM Tropics A, J. Atmos. Chem., 38, 317-344, 10.1023/A:1006402626288, 2001.

Cooper, P. L., and Abbatt, J. P. D.: Heterogeneous Interactions of $\mathrm{OH}$ and $\mathrm{HO}_{2}$ Radicals with surfaces characteristic of atmospheric particulate matter, J. Phys. Chem., 100, 2249-2254, 10.1021/jp952142z, 1996.

DeCarlo, P. F., Kimmel, J. R., Trimborn, A., Northway, M. J., Jayne, J. T., Aiken, A. C., Gonin, M., Fuhrer, K., Horvath, T., Docherty, K. S., Worsnop, D. R., and Jimenez, J. L.: Field-Deployable, High-Resolution, Time-of-Flight Aerosol Mass Spectrometer, Anal. Chem. 78, 8281-8289, 10.1021/ac061249n, 2006. Drinovec, L., Močnik, G., Zotter, P., Prévôt, A. S. H., Ruckstuhl, C., Coz, E., Rupakheti, M., Sciare, J., Müller, T., Wiedensohler, A., and Hansen, A. D. A.: The "dual-spot" Aethalometer: an improved measurement of aerosol black carbon with real-time loading compensation, Atmos. Meas. Tech., 8, 1965-1979, 10.5194/amt-8-1965-2015, 2015.

Fang, T., Guo, H., Zeng, L., Verma, V., Nenes, A., and Weber, R. J.: Highly acidic ambient particles, soluble metals, and oxidative potential: a link between sulfate and aerosol toxicity, Environ. Sci. Technol., 51, 2611-2620, 10.1021/acs.est.6b06151, 2017. 
Finlayson-Pitts, B. J., and Pitts, J. N.: CHAPTER 7 - Chemistry of inorganic nitrogen compounds, in: chemistry of the upper and lower atmosphere, edited by: Finlayson-Pitts, B. J., and Pitts, J. N., Academic Press, San Diego, 264-293, 2000.

Fountoukis, C., and Nenes, A.: ISORROPIA II: a computationally efficient thermodynamic equilibrium model for $\mathrm{K}^{+}-\mathrm{Ca}^{2+}-\mathrm{Mg}^{2+}-\mathrm{NH}_{4}{ }^{+}-\mathrm{Na}^{+}-\mathrm{SO}_{4}{ }^{2-}-\mathrm{NO}_{3}{ }^{-}-\mathrm{Cl}^{-}-\mathrm{H}_{2} \mathrm{O}$ aerosols, Atmos. Chem. Phys., 7, 4639-4659, 10.5194/acp-7-4639-2007, 2007.

George, I. J., and Abbatt, J. P.: Heterogeneous oxidation of atmospheric aerosol particles by gas-phase radicals, Nature chem., 2, 713-722, 10.1038/nchem.806, 2010.

George, I. J., Matthews, P. S. J., Whalley, L. K., Brooks, B., Goddard, A., Baeza-Romero, M. T., and Heard, D. E.: Measurements of uptake coefficients for heterogeneous loss of $\mathrm{HO}_{2}$ onto submicron inorganic salt aerosols, Phys. Chem. Chem. Phys., 15, 12829-12845, 10.1039/C3CP51831K, 2013.

Gershenzon, Y. M., Grigorieva, V. M., Ivanov, A. V., and Remorov, R. G.: $\mathrm{O}_{3}$ and $\mathrm{OH}$ Sensitivity to heterogeneous sinks of $\mathrm{HO}$ and $\mathrm{CH}_{3} \mathrm{O}_{2}$ on aerosol particles, Faraday Discuss., 100, 83-100, 10.1039/FD9950000083, 1995.

George, C., Ammann, M., and Volkamer, R.: Heterogeneous photochemistry of imidazole-2carboxaldehyde: $\mathrm{HO}_{2}$ radical formation and aerosol growth, Atmos. Chem. Phys., 16, 11823-11836, 10.5194/acp-16-11823-2016, 2016.

Gonzalez, J., Torrent-Sucarrat, M., and Anglada, J. M.: The reactions of $\mathrm{SO}_{3}$ with $\mathrm{HO}_{2}$ radical and $\mathrm{H}_{2} \mathrm{O} \cdots$ $\mathrm{HO}_{2}$ radical complex. Theoretical study on the atmospheric formation of $\mathrm{HSO}_{5}$ and $\mathrm{H}_{2} \mathrm{SO}_{4}$, Phys. Chem. Chem. Phys., 12, 2116-2125, 10.1039/B916659A, 2010.

González Palacios, L., Corral Arroyo, P., Aregahegn, K. Z., Steimer, S. S., Bartels-Rausch, T., Nozière, B., Guieu, C., Chester, R., Nimmo, M., Martin, J. M., Guerzoni, S., Nicolas, E., Mateu, J., and Keyse, S.: Atmospheric input of dissolved and particulate metals to the northwestern Mediterranean, Deep Sea Res. (2 Top. Stud. Oceanogr.), 44, 655-674, 10.1016/S0967-0645(97)88508-6, 1997.

Guo, J., Tilgner, A., Yeung, C., Wang, Z., Louie, P. K. K., Luk, C. W. Y., Xu, Z., Yuan, C., Gao, Y., Poon, S., Herrmann, H., Lee, S., Lam, K. S., and Wang, T.: Atmospheric peroxides in a polluted subtropical environment: seasonal variation, sources and sinks, and importance of heterogeneous processes, Environ. Sci. Technol., 48, 1443-1450, 10.1021/es403229x, 2014.

Guo, J., Wang, Z., Tao, W., and Zhang, X.: Theoretical evaluation of different factors affecting the $\mathrm{HO}_{2}$ uptake coefficient driven by aqueous-phase first-order loss reaction, Sci. Total Environ., 683, 146-153, 10.1016/j.scitotenv.2019.05.237, 2019.

Halstead, M. J. R., Cunninghame, R. G., and Hunter, K. A.: Wet deposition of trace metals to a remote site in Fiordland, New Zealand, Atmos. Environ., 34, 665-676, 10.1016/S1352-2310(99)00185-5, 2000. Hanson, D. R., Burkholder, J. B., Howard, C. J., and Ravishankara, A. R.: Measurement of hydroxyl and hydroperoxy radical uptake coefficients on water and sulfuric acid surfaces, J. Phys. Chem., 96, 49794985, 10.1021/j100191a046, 1992.

Hanson, D. R., Ravishankara, A. R., and Solomon, S.: Heterogeneous reactions in sulfuric acid aerosols: A framework for model calculations, J. Geophys. Res. Atmos., 99, 3615-3629, 10.1029/93jd02932, 1994.

Heard, D. E., and Pilling, M. J.: Measurement of $\mathrm{OH}$ and $\mathrm{HO}_{2}$ in the Troposphere, Chem. Rev., 103, 5163-5198, 10.1021/cr020522s, 2003.

Hennigan, C. J., Izumi, J., Sullivan, A. P., Weber, R. J., and Nenes, A.: A critical evaluation of proxy methods used to estimate the acidity of atmospheric particles, Atmos. Chem. Phys., 15, 2775-2790, 10.5194/acp-15-2775-2015, 2015.

Hofmann, H., Hoffmann, P., and Lieser, K. H.: Transition metals in atmospheric aqueous samples, analytical determination and speciation, Fresen. J. Anal. Chem., 340, 591-597, 10.1007/BF00322435, 1991.

Hsu, S.-C., Wong, G. T. F., Gong, G.-C., Shiah, F.-K., Huang, Y.-T., Kao, S.-J., Tsai, F., Candice Lung, S.-C., Lin, F.-J., Lin, I. I., Hung, C.-C., and Tseng, C.-M.: Sources, solubility, and dry deposition of aerosol trace elements over the East China Sea, Mar. Chem. 120, 116-127, 10.1016/j.marchem.2008.10.003, 2010. 

initial deployment of a field instrument for measurement of $\mathrm{OH}$ and $\mathrm{HO}_{2}$ in the troposphere by laserinduced fluorescence, J. Chem. Soc., Faraday Trans. 93, 2907-2913, 10.1039/A701469D, 1997.

George, I. J., Slowik, J., and Abbatt, J.: Chemical aging of ambient organic aerosol from heterogeneous reaction with hydroxyl radicals, Geophys. Res. Lett., 35, L13811, 10.1029/2008GL033884, 2008. 10.1016/S1352-2310(99)00462-8, 2000. Anderson, B., Gregory, G. L., Singh, H. B., Pueschel, R., Ferry, G., Blake, D. R., and Shetter, R. E.: Photochemistry of $\mathrm{HO} \mathrm{x}$ in the upper troposphere at northern midlatitudes, J. Geophys. Res. Atmos., 105, 3877-3892, doi:10.1029/1999JD901016, 2000.

Kanaya, Y., Cao, R., Akimoto, H., Fukuda, M., Komazaki, Y., Yokouchi, Y., Koike, M., Tanimoto, H., Takegawa, N., and Kondo, Y.: Urban photochemistry in central Tokyo: 1. Observed and modeled $\mathrm{OH}$ and $\mathrm{HO}_{2}$ radical concentrations during the winter and summer of 2004, J. Geophys. Res. Atmos., 112, 10.1029/2007jd008670, 2007a.

Kanaya, Y., Cao, R., Kato, S., Miyakawa, Y., Kajii, Y., Tanimoto, H., Yokouchi, Y., Mochida, M., Kawamura, K., and Akimoto, $\mathrm{H}$.: Chemistry of $\mathrm{OH}$ and $\mathrm{HO}_{2}$ radicals observed at Rishiri Island, Japan, in September 2003: Missing daytime sink of $\mathrm{HO}_{2}$ and positive nighttime correlations with monoterpenes, 112 , 10.1029/2006jd007987, 2007b.

Lakey, P. S. J., George, I. J., Whalley, L. K., Baeza-Romero, M. T., and Heard, D. E.: Measurements of the $\mathrm{HO}_{2}$ uptake coefficients onto single component organic aerosols, Environ. Sci. Technol., 49, 48784885, 10.1021/acs.est.5b00948, 2015.

Lakey, P. S. J., Berkemeier, T., Krapf, M., Dommen, J., Steimer, S. S., Whalley, L. K., Ingham, T., BaezaRomero, M. T., Pöschl, U., Shiraiwa, M., Ammann, M., and Heard, D. E.: The effect of viscosity and diffusion on the $\mathrm{HO}_{2}$ uptake by sucrose and secondary organic aerosol particles, Atmos. Chem. Phys., 16, 13035-13047, 10.5194/acp-16-13035-2016, 2016a.

Lakey, P. S. J., George, I. J., Baeza-Romero, M. T., Whalley, L. K., and Heard, D. E.: Organics substantially reduce $\mathrm{HO}_{2}$ uptake onto aerosols containing transition metal ions, J. Phys. Chem. A, 120, 1421-1430, 10.1021/acs.jpca.5b06316, 2016b.

Logan, J. A., Prather, M. J., Wofsy, S. C., and McElroy, M. B.: Tropospheric chemistry: A global perspective, 86, 7210-7254, 10.1029/JC086iC08p07210, 1981.

Loukhovitskaya, E., Bedjanian, Y., Morozov, I., and Le Bras, G.: Laboratory study of the interaction of $\mathrm{HO} 2$ radicals with the $\mathrm{NaCl}, \mathrm{NaBr}, \mathrm{MgCl}_{2} \cdot 6 \mathrm{H}_{2} \mathrm{O}$ and sea salt surfaces, Phys. Chem. Chem. Phys., 11, 7896-7905, 10.1039/B906300E, 2009.

Macintyre, H. L., and Evans, M. J.: Parameterisation and impact of aerosol uptake of $\mathrm{HO}_{2}$ on a global tropospheric model, Atmos. Chem. Phys., 11, 10965-10974, 10.5194/acp-11-10965-2011, 2011.

Manoj, S. V., Mishra, C. D., Sharma, M., Rani, A., Jain, R., Bansal, S. P., and Gupta, K. S.: Iron, manganese and copper concentrations in wet precipitations and kinetics of the oxidation of $\mathrm{SO}_{2}$ in rain water at two urban sites, Jaipur and Kota, in Western India, Atmos. Environ., 34, 4479-4486, 10.1016/S13522310(00)00117-5, 2000.

Mao, J., Jacob, D. J., Evans, M. J., Olson, J. R., Ren, X., Brune, W. H., Clair, J. M. S., Crounse, J. D., Spencer, K. M., Beaver, M. R., Wennberg, P. O., Cubison, M. J., Jimenez, J. L., Fried, A., Weibring, P., Walega, J. G., Hall, S. R., Weinheimer, A. J., Cohen, R. C., Chen, G., Crawford, J. H., McNaughton, C., Clarke, A. D., Jaeglé, L., Fisher, J. A., Yantosca, R. M., Le Sager, P., and Carouge, C.: Chemistry of hydrogen oxide radicals (HOx) in the Arctic troposphere in spring, Atmos. Chem. Phys., 10, 5823-5838, 10.5194/acp10-5823-2010, 2010.

Mao, J., Fan, S., Jacob, D. J., and Travis, K. R.: Radical loss in the atmosphere from Cu-Fe redox coupling in aerosols, Atmos. Chem. Phys., 13, 509-519, 10.5194/acp-13-509-2013, 2013a.

Mao, J., Paulot, F., Jacob, D. J., Cohen, R. C., Crounse, J. D., Wennberg, P. O., Keller, C. A., Hudman, R. C., Barkley, M. P., and Horowitz, L. W.: Ozone and organic nitrates over the eastern United States: 

2013b. Williams, E., Stroud, C., Jobson, B., Roberts, J. M., Hall, S., Shetter, R., Wert, B. P., Fried, A., Alicke, B., Stutz, J., Young, V., White, A., and Zamora, R. J.: $\mathrm{OH}$ and $\mathrm{HO}_{2}$ concentrations, sources, and loss rates during the Southern Oxidants Study in Nashville, Tennessee, summer 1999, J. Geophys. Res., 108, 2003. Matthews, P. S. J., Baeza-Romero, M. T., Whalley, L. K., and Heard, D. E.: Uptake of $\mathrm{HO}_{2}$ radicals onto Arizona test dust particles using an aerosol flow tube, Atmos. Chem. Phys., 14, 7397-7408, 10.5194/acp-14-7397-2014, 2014.

Millán, L., Wang, S., Livesey, N., Kinnison, D., Sagawa, H., and Kasai, Y.: Stratospheric and mesospheric $\mathrm{HO}_{2}$ observations from the Aura Microwave Limb Sounder, Atmos. Chem. Phys., 15, 2889-2902, 10.5194/acp-15-2889-2015, 2015.

Miyazaki, K., Nakashima, Y., Schoemaecker, C., Fittschen, C., and Kajii, Y.: Note: A laser-flash photolysis and laser-induced fluorescence detection technique for measuring total $\mathrm{HO}_{2}$ reactivity in ambient air, Rev. Sci. Instrum., 84, 076106, 10.1063/1.4812634, 2013.

Moon, D. R.; Taverna, G. S.; Anduix-Canto, C.; Ingham, T.; Chipperfield, M. P.; Seakins, P. W.; BaezaRomero, M. T.; Heard, D. E., Heterogeneous reaction of $\mathrm{HO}_{2}$ with airborne $\mathrm{TiO}_{2}$ particles and its implication for climate change mitigation strategies. Atmos. Chem. Phys. 2018, 18, (1), 327-338.

Morita, A., Kanaya, Y., and Francisco, J. S.: Uptake of the $\mathrm{HO}_{2}$ radical by water: Molecular dynamics calculations and their implications for atmospheric modeling, J. Geophys. Res. Atmos., 109, 10.1029/2003jd004240, 2004.

Mozurkewich, M., McMurry, P. H., Gupta, A., and Calvert, J. G.: Mass accommodation coefficient for $\mathrm{HO}_{2}$ radicals on aqueous particles, J. Geophys. Res. Atmos., 92, 4163-4170, 10.1029/JD092iD04p04163, 1987.

Ng, N. L., Canagaratna, M. R., Jimenez, J. L., Chhabra, P. S., Seinfeld, J. H., and Worsnop, D. R.: Changes in organic aerosol composition with aging inferred from aerosol mass spectra, Atmos. Chem. Phys., 11, 6465-6474, 10.5194/acp-11-6465-2011, 2011.

Oakes, M., Weber, R. J., Lai, B., Russell, A., and Ingall, E. D.: Characterization of iron speciation in urban and rural single particles using XANES spectroscopy and micro X-ray fluorescence measurements: investigating the relationship between speciation and fractional iron solubility, Atmos. Chem. Phys., 12, 745-756, 10.5194/acp-12-745-2012, 2012.

Remorov, R. G., Gershenzon, Y. M., Molina, L. T., and Molina, M. J.: Kinetics and mechanism of $\mathrm{HO}_{2}$ uptake on solid NaCl, J. Phys. Chem. A, 106, 4558-4565, 10.1021/jp013179o, 2002.

Ross, H. B., and Noone, K. J.: A numerical investigation of the destruction of peroxy radical by $\mathrm{Cu}$ ion catalysed reactions on atmospheric particles, J. Atmos. Chem., 12, 121-136, 10.1007/BF00115775, 1991.

Saathoff, H., Naumann, K.-H., Riemer, N., Kamm, S., Möhler, O., Schurath, U., Vogel, H., and Vogel, B.: The loss of $\mathrm{NO}_{2}, \mathrm{HNO}_{3}, \mathrm{NO}_{3} / \mathrm{N}_{2} \mathrm{O}_{5}$, and $\mathrm{HO}_{2} / \mathrm{HOONO}$ on soot aerosol: A chamber and modeling study, Geophys. Res. Lett., 28, 1957-1960, 10.1029/2000gl012619, 2001.

Sadanaga, Y., Yoshino, A., Watanabe, K., Yoshioka, A., Wakazono, Y., Kanaya, Y., and Kajii, Y.: Development of a measurement system of $\mathrm{OH}$ reactivity in the atmosphere by using a laser-induced pump and probe technique, Rev. Sci. Instrum., 75, 2648-2655, 10.1063/1.1775311, 2004.

Sakamoto, Y., Zhou, J., Kohno, N., Nakagawa, M., Hirokawa, J., and Kajii, Y.: Kinetics study of OH uptake onto deliquesced $\mathrm{NaCl}$ particles by combining Laser Photolysis and Laser-Induced Fluorescence, J. Phys. Chem. Lett., 9, 4115-4119, 10.1021/acs.jpclett.8b01725, 2018.

Sakamoto, Y., Sadanaga, Y., Li, J., Matsuoka, K., Takemura, M., Fujii, T., Nakagawa, M., Kohno, N., Nakashima, Y., Sato, K., Nakayama, T., Kato, S., Takami, A., Yoshino, A., Murano, K., and Kajii, Y.: Relative and absolute sensitivity analysis on ozone production in Tsukuba, a city in Japan, Environ. Sci. Technol., 53, 13629-13635, 10.1021/acs.est.9b03542, 2019.

Sedlak, D. L., and Hoigné, J.: The role of copper and oxalate in the redox cycling of iron in atmospheric waters, Atmos. Environ., Part A. General Topics, 27, 2173-2185, 10.1016/0960-1686(93)90047-3, 1993. 
Siefert, R. L., Johansen, A. M., Hoffmann, M. R., and Pehkonen, S. O.: Measurements of trace metal

718 (Fe, Cu, Mn, Cr) oxidation states in fog and stratus clouds, J. Air Waste Manage, 48, 128-143, 719 10.1080/10473289.1998.10463659, 1998.

Sommariva, R., Haggerstone, A. L., Carpenter, L. J., Carslaw, N., Creasey, D. J., Heard, D. E., Lee, J. D., Lewis, A. C., Pilling, M. J., and Zádor, J.: $\mathrm{OH}$ and $\mathrm{HO}_{2}$ chemistry in clean marine air during SOAPEX-2, Atmos. Chem. Phys., 4, 839-856, 10.5194/acp-4-839-2004, 2004. Scharr, A., and Zhang, Y.: Influence of aerosol copper on $\mathrm{HO}_{2}$ uptake: A novel parameterized equation, Atmos. Chem. Phys. Discuss., 2020, 1-23, 10.5194/acp-2020-218, 2020.

Stadtler, S., Simpson, D., Schröder, S., Taraborrelli, D., Bott, A., and Schultz, M.: Ozone impacts of gasaerosol uptake in global chemistry transport models, Atmos. Chem. Phys., 18, 3147-3171, 10.5194/acp-18-3147-2018, 2018.

Stone, D., Whalley, L. K., and Heard, D. E.: Tropospheric $\mathrm{OH}$ and $\mathrm{HO}_{2}$ radicals: field measurements and model comparisons, Chem. Soc. Rev., 41, 6348-6404, 10.1039/C2CS35140D, 2012.

Takami, A., Mayama, N., Sakamoto, T., Ohishi, K., Irei, S., Yoshino, A., Hatakeyama, S., Murano, K., Sadanaga, Y., Bandow, H., Misawa, K., and Fujii, M.: Structural analysis of aerosol particles by microscopic observation using a time-of-flight secondary ion mass spectrometer, J. Geophys. Res. Atmos., 118, 6726-6737, 10.1002/jgrd.50477, 2013.

Taketani, F., Kanaya, Y., and Akimoto, $\mathrm{H}$. : Kinetics of heterogeneous reactions of $\mathrm{HO}_{2}$ radical at ambient concentration levels with $\left(\mathrm{NH}_{4}\right)_{2} \mathrm{SO}_{4}$ and $\mathrm{NaCl}$ aerosol particles, J. Phys. chem. A, 112, 23702377, 10.1021/jp0769936, 2008.

Taketani, F.; Kanaya, Y.; Akimoto, H., Heterogeneous loss of $\mathrm{HO}_{2}$ by $\mathrm{KCl}$, synthetic sea salt, and natural seawater aerosol particles. Atmospheric Environment 2009, 43, (9), 1660-1665.

Taketani, F., Kanaya, Y., Pochanart, P., Liu, Y., Li, J., Okuzawa, K., Kawamura, K., Wang, Z., and Akimoto, $\mathrm{H}$.: Measurement of overall uptake coefficients for $\mathrm{HO}_{2}$ radicals by aerosol particles sampled from ambient air at Mts. Tai and Mang (China), Atmos. Chem. Phys., 12, 11907-11916, 10.5194/acp-1211907-2012, 2012.

Thornton, J., and Abbatt, J. P. D.: Measurements of $\mathrm{HO}_{2}$ uptake to aqueous aerosol: Mass accommodation coefficients and net reactive loss, J. Geophys. Res. Atmos., 110, 10.1029/2004jd005402, 2005.

Thornton, J. A., Jaeglé, L., and McNeill, V. F.: Assessing known pathways for $\mathrm{HO}_{2}$ loss in aqueous atmospheric aerosols: Regional and global impacts on tropospheric oxidants, J. Geophys. Res. Atmos., 113, 10.1029/2007jd009236, 2008.

Tie, X., Brasseur, G., Emmons, L., Horowitz, L., and Kinnison, D.: Effects of aerosols on tropospheric oxidants: A global model study, J. Geophys. Res. Atmos., 106, 22931-22964, 10.1029/2001JD900206, 2001.

Wang, Y., Arellanes, C., Curtis, D. B., and Paulson, S. E.: Probing the source of hydrogen peroxide associated with coarse mode aerosol particles in southern california, Environ. Sci. Technol., 44, 40704075, 10.1021/es100593k, 2010.

Whalley, L. K., Furneaux, K. L., Goddard, A., Lee, J. D., Mahajan, A., Oetjen, H., Read, K. A., Kaaden, N., Carpenter, L. J., Lewis, A. C., Plane, J. M. C., Saltzman, E. S., Wiedensohler, A., and Heard, D. E.: The chemistry of $\mathrm{OH}$ and $\mathrm{HO}_{2}$ radicals in the boundary layer over the tropical Atlantic Ocean, Atmos. Chem. Phys., 10, 1555-1576, 10.5194/acp-10-1555-2010, 2010.

Wilkinson, J., Reynolds, B., Neal, C., Hill, S., Neal, M., and Harrow, M.: Major, minor and trace element composition of cloudwater and rainwater at Plynlimon, Hydrol. Earth Syst. Sci., 1, 557-569, 10.5194/hess-1-557-1997, 1997.

Zhou, J., Elser, M., Huang, R. J., Krapf, M., Fröhlich, R., Bhattu, D., Stefenelli, G., Zotter, P., Bruns, E. A., Pieber, S. M., Ni, H., Wang, Q., Wang, Y., Zhou, Y., Chen, C., Xiao, M., Slowik, J. G., Brown, S., Cassagnes, L. E., Daellenbach, K. R., Nussbaumer, T., Geiser, M., Prévôt, A. S. H., El-Haddad, I., Cao, J., Baltensperger, U., and Dommen, J.: Predominance of secondary organic aerosol to particle-bound 
https://doi.org/10.5194/acp-2020-1214

Preprint. Discussion started: 18 January 2021

(C) Author(s) 2021. CC BY 4.0 License.

767 reactive oxygen species activity in fine ambient aerosol, Atmos. Chem. Phys., 19, 14703-14720,

768 10.5194/acp-19-14703-2019, 2019a.

769 Zhou, J., Murano, K., Kohno, N., Sakamoto, Y., and Kajii, Y.: Real-time quantification of the total $\mathrm{HO}_{2}$

770 reactivity of ambient air and $\mathrm{HO}_{2}$ uptake kinetics onto ambient aerosols in Kyoto (Japan), Atmosp.

771 Environ., 117189, 10.1016/j.atmosenv.2019.117189, 2019b.

772 